Review

\title{
Prospects for Using Expression Patterns of Paramyxovirus Receptors as Biomarkers for Oncolytic Virotherapy
}

\author{
Olga V. Matveeva ${ }^{1, *(1)}$ and Svetlana A. Shabalina ${ }^{2, *}$ \\ 1 Sendai Viralytics LLC, 23 Nylander Way, Acton, MA 01720, USA \\ 2 National Center for Biotechnology Information, National Library of Medicine, National Institutes of Health, \\ Bethesda, MD 20894, USA \\ * Correspondence: olga.matveeva@gmail.com (O.V.M.); shabalin@ncbi.nlm.nih.gov (S.A.S.)
}

Received: 27 October 2020; Accepted: 1 December 2020; Published: 5 December 2020

check for updates

Simple Summary: Some non-pathogenic viruses that do not cause serious illness in humans can efficiently target and kill cancer cells and may be considered candidates for cancer treatment with virotherapy. However, many cancer cells are protected from viruses. An important goal of personalized cancer treatment is to identify viruses that can kill a certain type of cancer cells. To this end, researchers investigate expression patterns of cell entry receptors, which viruses use to bind to and enter host cells. We summarized and analyzed the receptor expression patterns of two paramyxoviruses: The non-pathogenic measles and the Sendai viruses. The receptors for these viruses are different and can be proteins or lipids with attached carbohydrates. This review discusses the prospects for using these paramyxovirus receptors as biomarkers for successful personalized virotherapy for certain types of cancer.

\begin{abstract}
The effectiveness of oncolytic virotherapy in cancer treatment depends on several factors, including successful virus delivery to the tumor, ability of the virus to enter the target malignant cell, virus replication, and the release of progeny virions from infected cells. The multi-stage process is influenced by the efficiency with which the virus enters host cells via specific receptors. This review describes natural and artificial receptors for two oncolytic paramyxoviruses, nonpathogenic measles, and Sendai viruses. Cell entry receptors are proteins for measles virus (MV) and sialylated glycans (sialylated glycoproteins or glycolipids/gangliosides) for Sendai virus (SeV). Accumulated published data reviewed here show different levels of expression of cell surface receptors for both viruses in different malignancies. Patients whose tumor cells have low or no expression of receptors for a specific oncolytic virus cannot be successfully treated with the virus. Recent published studies have revealed that an expression signature for immune genes is another important factor that determines the vulnerability of tumor cells to viral infection. In the future, a combination of expression signatures of immune and receptor genes could be used to find a set of oncolytic viruses that are more effective for specific malignancies.
\end{abstract}

Keywords: oncolytic viruses; oncolytic virotherapy; viral oncolysis; measles virus; Sendai virus; biomarkers; virus receptors; receptor retargeting; virus receptor expression; protein receptors; glycosphingolipid receptors; gangliosides

\section{Introduction}

Oncolytic viruses are promising new agents for cancer treatment. They can kill cancer cells directly through infection or indirectly through activation of the immune system [1,2]. For the most effective 
virotherapy, elimination of malignant cells with a combination of both direct and indirect destruction is desirable. Like all viruses, oncolytic viruses use specific receptors to bind to and enter host cells. This review describes the tendency of tumor cells to overexpress certain viral receptors, but it also shows that, to varying degrees, these receptors are also expressed in many normal cells. However, regardless of whether cells are normal or malignant, absence of receptors for a particular virus makes the cells resistant to this virus infection. So, for better identification of individual patients who are most likely to benefit from virotherapy, their tumor cells should be screened for the presence of virus receptors. For many oncolytic viruses, such receptors are well characterized. Thus, simple tests that evaluate protein or RNA levels in tumor tissue could provide information about expression levels of a virus receptor.

Receptor mediated virus entry into a cell is only the first step in viral infection. Next, the virus must break through the cellular antiviral defense system, which usually effectively protects normal cells from any virus infection. Key players in such protection are interferons (IFNs); they help cells detect the presence of a virus and, in response, restrict proliferation, slow down metabolic processes, and trigger apoptosis [3,4]. However, malignant cells frequently have dysfunctional IFN pathways. Such dysfunction helps them to evade the immune system and survive, thus promoting tumor growth. The same IFN defects that help cancer cells escape immune surveillance make them vulnerable to virus infection [5]. Nevertheless, not all malignant cells have dysfunctional IFN pathways. Some of them can produce and/or respond to IFN signals and protect themselves from a virus infection. So, theoretically, even if a cancer cell had receptors for a particular oncolytic virus it still could be resistant to infection by the virus.

Some viruses require cells to express processing enzymes that modify or cleave the viral proteins necessary for the formation of mature infectious virions. Thus, fusion protein in paramyxoviruses is synthesized as an inactive precursor and is activated through proteolytic cleavage by the cellular protease. Without such cleavage the virus is unable to sustain infection. For MV, this activating protease is furin [6] and for SeV it can be a number of serine proteases (TPSB2 [7-9], PRSS1 [10], PLG [11], F10 [12], and TMPRSS2 [13]). Some of these proteases are overexpressed in cancer cells [14-16]. In addition to those listed, the expression levels of other host genes influence vulnerability of cancer cells to a virus infection. Figure 1 illustrates factors necessary for a cell to become vulnerable to paramyxovirus infection.

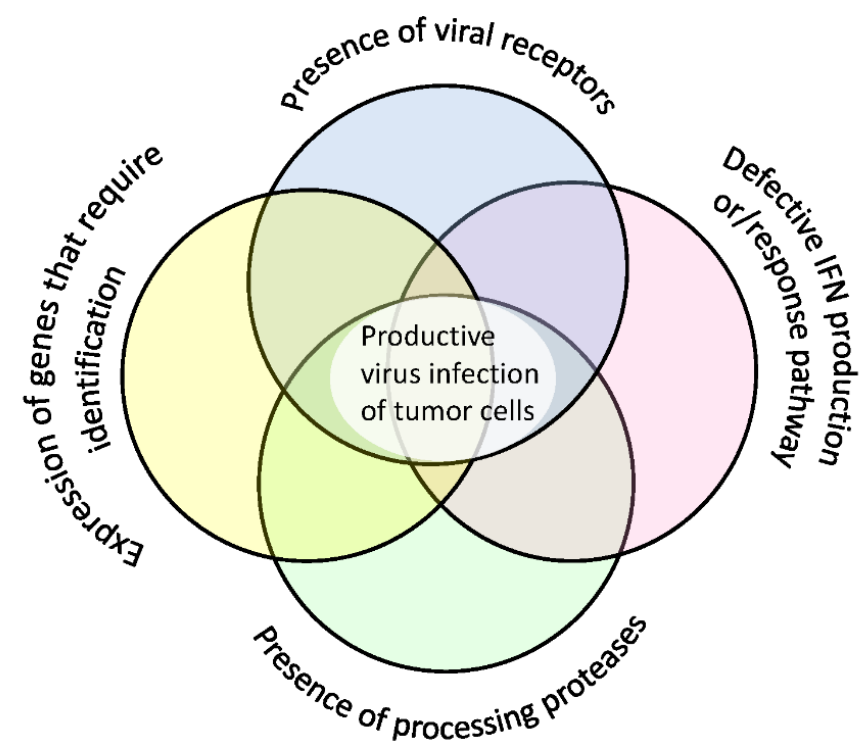

Figure 1. Factors influencing cells' vulnerability to paramyxovirus infection. The host cell needs to (1) express virus receptors (2) have a malfunctioning IFN pathway, (3) express proteases responsible for proteolytic activation of virus fusion rotein, and (4) have other genes that require further identification. 
To predict if a patient is likely to respond to oncolytic virotherapy, testing for the presence of virus receptors in tumor tissue is not sufficient. Additional tests are also needed to reveal the presence of impaired IFN signaling in the patient's cancer cells, and the expression of virus processing enzymes and yet to be identified other proteins that accommodate virus infection. Currently, such tests are commercially unavailable and need to be developed to optimize patient selection protocols for future clinical trials.

Oncolytic paramyxoviruses might become powerful anticancer agents [17-19]. Figure 2 shows the life cycle of the viruses, which can trigger syncytium (a polykarion) formation that protects virions from host neutralizing antibodies during intratumor virus replication and spreading.

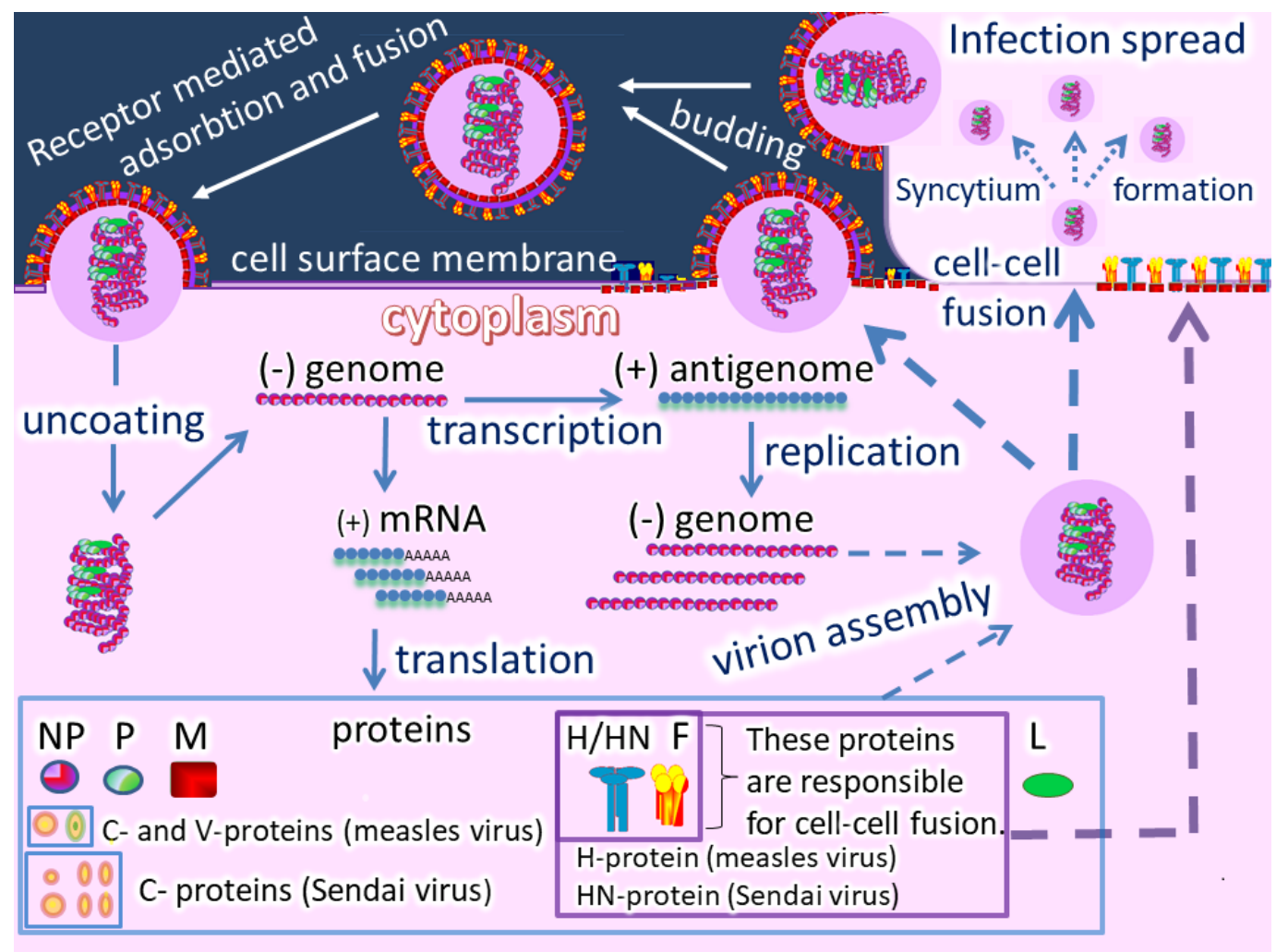

Figure 2. A visual representation of the cell cycle of measles virus (MV) and Sendai virus (SeV). Both viruses belong to the Paramyxoviridae family, but MV belongs to the Morbillivirus genus and $\mathrm{SeV}$ to the Respirovirus genus. The life cycles of MV and $\mathrm{SeV}$ are very similar, but there are several important differences. Their attachment to host cells occurs through different cell entry receptors and different viral cell attachment proteins. The MV virus uses an $\mathrm{H}$ protein with hemagglutinin activity, while $\mathrm{SeV}$ uses the HN protein with hemagglutinin $(\mathrm{H})$ and neuraminidase $(\mathrm{N})$ activities. In addition to these proteins, the genomes of these viruses encode 5 structural proteins and accessary proteins. The main structural proteins for both viruses are: Nucleoprotein (N), Phosphoprotein (P), Matrix protein (M), Fusion protein $(\mathrm{F})$, and Large Protein (L). The MV genome encodes two non-structural proteins, $\mathrm{C}$ and $\mathrm{V},[20]$, while the $\mathrm{SeV}$ genome encodes a set of non-structural proteins, collectively referred as C-proteins (C', C, Y1, Y2, V, W) [21]. Viral replication for MV and SeV follows a negative-stranded RNA virus replication model in which genomic RNA (minus strand) is used as a template to create a copy of positive sense RNA, employing the RNA-dependent RNA polymerase embedded in the virion. The plus RNA is further used as a template for making multiple copies of the minus RNA. The plus RNA is also translated by the host's ribosomes, producing all viral proteins. Viruses are then assembled from these proteins along with genomic RNA and budded from the host cell. Both MV and $\mathrm{SeV}$ can form syncytia by fusing neighboring infected and non-infected cells into a polykayion. 
So, two related processes can occur: Efficient intratumor virus spread and the resulting mass death of malignant cells. In general, oncolytic paramyxoviruses stimulate strong innate and adaptive anticancer immune responses by generating multiple danger signals. They are potent inducers of IFN and other immuno-stimulating cytokines, and they efficiently induce anticancer activity of natural killer cells, dendritic cells, and cytotoxic T lymphocytes [18]. Finally, the viruses require proteolytic cleavage of their fusion proteins by cellular serine proteases, which are sometimes overexpressed in cancer cells [14-16], and could add an additional level of specificity to viral oncolytic activity. Moreover, the gene that encodes a fusion protein in the paramyxovirus genome can be replaced with a constructed fusion protein that could be processed by tumor-associated matrix metalloproteases.

The purpose of this review is to summarize and analyze information related to expression patterns of receptors for oncolytic paramyxoviruses (both natural and artificially retargeted). In current literature and existing databases, receptor expression patterns are evaluated by quantitative and semi-quantitative measurements of RNA or protein. Analysis of the collected information may ultimately aid in the development of tests to identify oncolytic viruses that are more effective against specific malignancies. To compare expression levels in normal and cancerous tissues for each studied virus receptor, we analyzed a Human Protein Atlas (HPA) database [15,16,22]. HPA accumulates protein expression information from experiments performed by HPA project participants along with RNA-Seq information from The Cancer Genome Atlas (TCGA), Genotype-Tissue Expression (GTEx) and Functional Annotation of the Mammalian Genomes (FANTOM5) project databases [16]. We also analyzed relevant literature and gene expression patterns in the PubMed database.

Several paramyxovirus representatives have oncolytic properties. Among them are attenuated measles and mumps viruses, Newcastle disease virus, and SeV [17,18]. In this review, information related to $\mathrm{MV}$ and $\mathrm{SeV}$ receptors is compiled and analyzed.

\section{Measles Virus as an Oncolytic Agent}

MV (Box 1, Figure 3) causes a highly contagious disease transmitted by respiratory aerosols that can trigger severe immunosuppression and even immune amnesia.

Box 1. Measles Virus (MV).

\footnotetext{
Taxonomy: The virus belongs to the genus Morbillivirus within the family Paramyxoviridae [23,24].

Host: Human

Origin: Most likely MV originated from a virus of non-human species.

Genome: MV has a single-stranded, negative-sense, non-segmented RNA genome that is 16K nucleotides long. Virion: MV is an enveloped virus with a lipid membrane.

Proteins: Nucleoprotein $(\mathrm{N})$, phosphoprotein $(\mathrm{P})$, matrix protein $(\mathrm{M})$, fusion protein $(\mathrm{F})$, hemagglutinin $(\mathrm{H})$, large protein $(\mathrm{L})$, and two nonstructural proteins $\mathrm{C}$ and V. Protein $\mathrm{C}$ is translated from the same mRNA as the $P$ protein but using an alternative start codon in an overlapping ORF. Protein $\mathrm{V}$ is translated from an edited P mRNA.
}

Significant efforts by virologists in the second half of the 20th century were focused on finding a safe and effective vaccine against MV. In 1954, one MV isolated strain, when passaged in cell culture, gradually lost its pathogenicity, and became attenuated. From this attenuated variant of the virus, one of the first vaccine strain (Edmonston, denoted in the following text as MV-Edm) was obtained. Further passages of MV-Edm generated the more attenuated Schwarz and Moraten strains, which are still in use for vaccination against measles [24,25].

During the 20th century clinicians reported on isolated cases where measles disease relieved or caused remission of certain malignancies. Reports include descriptions of the regression of a number of hematological malignancies that took place after MV infection (reviewed in [26]). At the end of the century, virologists and oncologists started to investigate oncolytic properties of attenuated MV strains that are incapable of causing serious infection. 


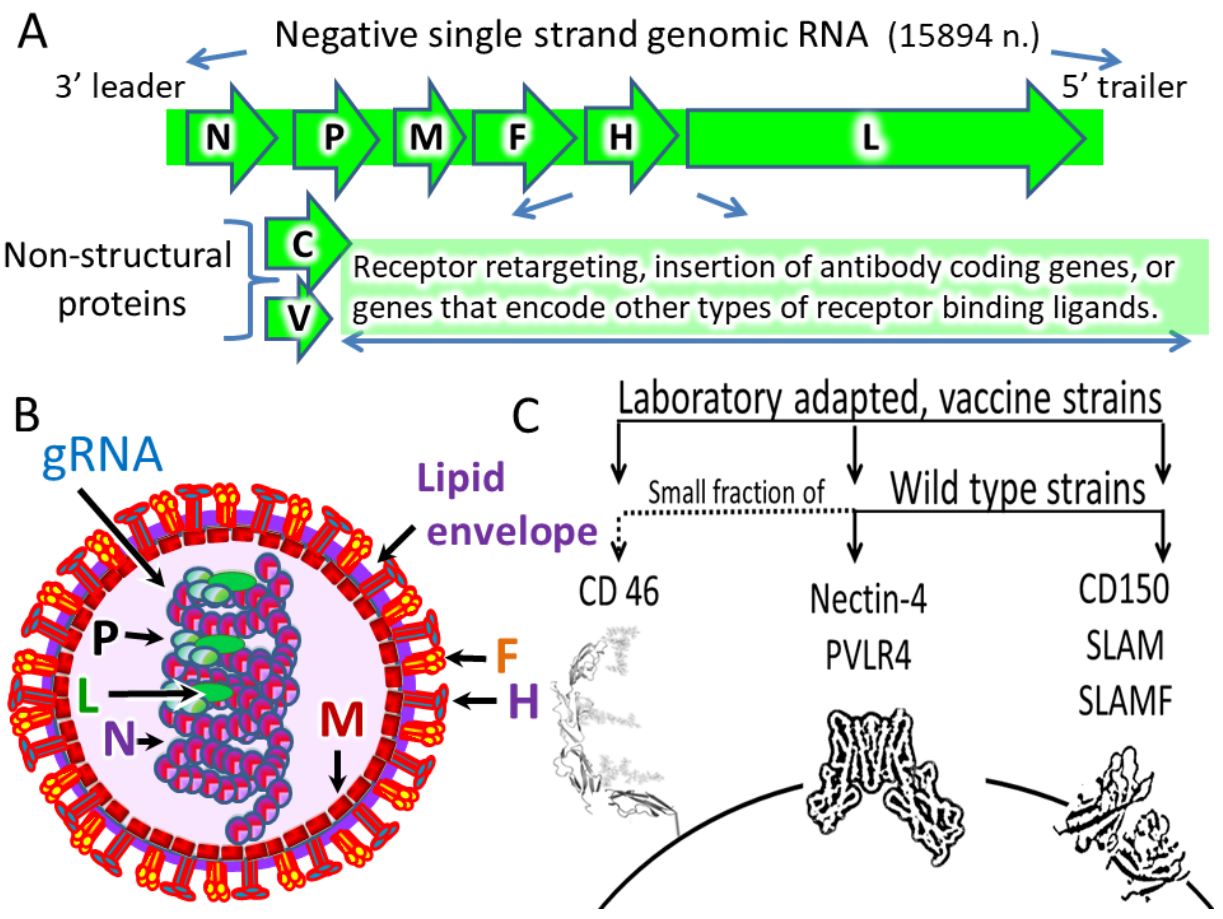

Figure 3. Schematic representation of the MV genome (A), virion (B) and host cell entry receptors (C). The RNA genome (gRNA) contains six transcription units that codes 6 main structural proteins: nucleoprotein $(\mathrm{N})$, phosphoprotein $(\mathrm{P})$, matrix protein $(\mathrm{M})$, fusion protein $(\mathrm{F})$, hemagglutinin $(\mathrm{H})$, and large protein (L) RNA dependent RNA polymerase (RdRp). The viral genome also codes the nonstructural $\mathrm{V}$ and $\mathrm{C}$ proteins, which are antagonists of host innate immunity. The transcription units for each structural gene are separated by non-transcribed trinucleotide intergenic sequences and together are flanked by short leader and trailer sequences containing the genomic promoter (on the minus strand) and the antigenomic promoter (on the plus strand). Inside the virion, genomic RNA forms a complex with $\mathrm{N}, \mathrm{L}$, and $\mathrm{P}$ proteins. The virus is enveloped by a lipid membrane that has glycoproteins $\mathrm{H}$ and $\mathrm{F}$ associated with it as virion surface proteins. These proteins coordinate how the virus finds cells and enters them. For $\mathrm{H}$ protein, three receptors have been identified: Complement regulatory molecule CD46, the cell adhesion molecule nectin- 4 and the signaling lymphocyte activation molecule (SLAM). MV wild-type strains use SLAM and nectin-4 as cell entry receptors. Vaccine strains and a small fraction of wild type strains, in addition, use CD46 as a cell entry receptor.

MV-Edm and its derivatives were the primary strains tested as oncolytic agents $[27,28]$. These strains can infect and kill a wide variety of cancer cells in vitro and in vivo. They are currently being investigated preclinically and in clinical trials for treatment of a large spectrum of malignancies, including ovarian, breast, head and neck cancers, as well as glioblastoma, multiple myeloma, mesothelioma, and T-cell lymphoma $[27,28]$. A virus with oncolytic properties can be delivered not only locally intratumorally, but also systemically, including by intraperitoneal and intravenous injection routes. In some trials patients survival compared favorably with that of historical controls and the side effects of the virotherapy were mainly mild $[27,28]$.

\section{Natural MV Receptors}

For wild type and vaccine MV strains, the proteins CD150 (SLAM or SLAMF1) [29,30] and/or nectin-4 (also called poliovirus-receptor-like 4 (PVRL4)) [31-33] function mainly as cell entry receptors. A small fraction of wild type MV strains and all modern vaccine strains derived from the Edmonston strain also use CD46 receptors (Table 1, Figure 3C) [34,35]. 
Table 1. Natural receptors for MV and their expression in normal cells.

\begin{tabular}{|c|c|c|}
\hline Receptor & High Expression in Normal Cells & Expression Evaluation \\
\hline \multirow{2}{*}{ CD150/SLAM } & $\begin{array}{l}\text { Hematopoietic stem and progenitor cells } \\
\text { including T, B, natural killer, } \\
\text { and dendritic cells [36-38] }\end{array}$ & Multicolor flow-cytometry \\
\hline & $\begin{array}{l}\text { Spleen red pulp cells and thymus cortical } \\
\text { and medullary cells [14-16] }\end{array}$ & $\begin{array}{l}\text { Immunohistochemical } \\
\text { tissue staining } \\
\text { AB: HPA069319,CAB002438 }\end{array}$ \\
\hline Nectin-4/PVLR 4 & $\begin{array}{l}\text { Glandular cells of breast, stomach colon, } \\
\text { gall bladder and others [14-16] }\end{array}$ & $\begin{array}{l}\text { Immunohistochemical tissue } \\
\text { staining } \\
\text { AB: HPA016903,CAB010401 }\end{array}$ \\
\hline CD46/membrane cofactor protein & $\begin{array}{l}\text { Glandular cells of breast, stomach, colon } \\
\text { and others [14-16] }\end{array}$ & $\begin{array}{l}\text { Immunohistochemical tissue } \\
\text { staining } \\
\text { AB: HPA010775 }\end{array}$ \\
\hline
\end{tabular}

Abbreviations: AB: Antibodies.

RNA and protein expression patterns of MV receptors are estimated by several different approaches, including array technology, quantitative RT-PCR and RNA-Seq for RNAs, as well as immunohistochemical tissue staining, flow cytometry and western blotting for proteins. Tables 1 and 2 respectively summarize expression patterns of natural MV receptors described in normal and malignant cells.

Table 2. Expression of natural MV-Edm receptors in malignancies.

\begin{tabular}{|c|c|c|c|}
\hline Malignancy & $\begin{array}{l}\text { CD150/SLAM } \\
\text { (Ref/Evidence) }\end{array}$ & $\begin{array}{l}\text { CD46/Membrane Cofactor Protein } \\
\text { (Ref/Evidence) }\end{array}$ & $\begin{array}{c}\text { Nectin-4 } \\
\text { (Ref/Evidence) }\end{array}$ \\
\hline Breast cancer & & [39]/IS, [14-16]/IS, TCGA dataset & {$[33,40-45] /$ IS, FC, PCR } \\
\hline Cervical cancer & & [14-16]/IS, TCGA dataset & \\
\hline Colorectal cancer & & $\begin{array}{l}\text { [14-16]/IS, TCGA dataset, } \\
\text { [46]/oligo-array }\end{array}$ & $\begin{array}{l}{[14-16,33,45,46] / \text { IS, }} \\
\text { TCGA dataset }\end{array}$ \\
\hline Endometrial cancer & & [14-16]/IS, TCGA dataset & \\
\hline Glioma & & [47] IS, FC & \\
\hline Liver cancer & & [14-16]/IS TCGA dataset & [48]/PCR, IS \\
\hline Lung cancer & & [14-16]/1S, ICGA dataset & {$[33,49] /$ IS, ELISA } \\
\hline Non-small cell lung cancer & & [50] IS, FC & [46]/Oligo-array \\
\hline Lymphoma & [51]/PCR, IS, WB, FC & [52] IS, FC & \\
\hline Melanoma & & [14-16]/IS, TCGA & \\
\hline Multiple myeloma & & [53]/IS, [46]/Oligo-array & \\
\hline Ovarian cancer & & [54]/IS, WB & {$[55,56] / \mathrm{PCR}, \mathrm{IS}, \mathrm{WB}, \mathrm{FC}$} \\
\hline Pancreatic cancer & & & [57]/IS \\
\hline Prostate cancer & & [14-16]/IS, TCGA dataset & \\
\hline Stomach cancer & & & \\
\hline Thyroid cancer & & & [14-16]/IS, TCGA dataset \\
\hline Urothelial cancer & & [14-16]/IS, TCGA dataset & \\
\hline
\end{tabular}

Abbreviations: IS: Immunohistochemical staining; FC: Flow Cytometry; PCR: Quantitative RT-PCR; TCGA: Tissue Cancer Genome Atlas; WB: Western immunoblotting.

CD150 (also called signaling lymphocytic activation molecule 1 (SLAM or SLAMF1)) is a transmembrane glycoprotein member of the signaling lymphocytic activation molecule family. It modulates the activation and differentiation of a wide variety of immune cells and is involved in the regulation of both innate and adaptive immune responses [36,58-60]. CD150 is expressed on the surface of hematopoietic stem and progenitor cells including natural killer cells, dendritic cells, and memory B and T cells [36-38] (Table 1). Therefore, wild-type MV can infect various cells that are involved in the host's immune response, resulting in strong immunosuppressive effects and erasure of immune memory from previous pathogen infections, causing immune amnesia [61,62].

In Japan, a set of MV-based oncolytic constructs was produced by removing MV's ability to interact with CD150 [63-65]. The removal of interaction ability between a virus and its receptor is called "blinding". It has been demonstrated that "blinding" results in the pathogenicity loss of the constructs, 
effectively making the MV strains non-infective to monkeys [66]. However, the constructs maintain the ability to kill malignant cells, including tumors, in model animals [63-65]. Three types of human malignancies were tested as murine xenografts, including breast, pancreatic, and lung carcinomas. The animals treated with intratumoral injections of the experimental constructs survived longer (Table 3).

Table 3. Retargeting MV receptors by blinding to CD150.

\begin{tabular}{|c|c|c|c|c|}
\hline Blinding to & Effect & $\begin{array}{l}\text { Cell Type or } \\
\text { Malignancy }\end{array}$ & $\begin{array}{l}\text { Model and Type } \\
\text { of Virus Delivery } \\
\text { to Animals }\end{array}$ & Reference \\
\hline \multirow{2}{*}{$\begin{array}{l}\text { CD150/SLAM, } \\
\text { no natural CD46 }\end{array}$} & $\begin{array}{l}\text { Viability of CD150-positive lymphoid } \\
\text { cells unaffected; reduced infection of } \\
\text { CD46-positive primary normal human } \\
\text { cells; tumor stabilized or regressed }\end{array}$ & Breast carcinoma & $\begin{array}{l}\text { Xenografts; } \\
\text { IT virus delivery }\end{array}$ & [63] \\
\hline & $\begin{array}{l}\text { Tumor stabilized; } \\
\text { animal survival prolonged }\end{array}$ & $\begin{array}{l}\text { Pancreatic } \\
\text { carcinomas } \\
\text { Lung carcinoma }\end{array}$ & $\begin{array}{l}\text { Xenografts; } \\
\text { IT virus delivery }\end{array}$ & $\begin{array}{l}{[64]} \\
{[65]}\end{array}$ \\
\hline
\end{tabular}

Nevertheless, some malignancies do overexpress CD150. Many cell lines generated from Hodgkin's and Burkitt's lymphomas are characterized by very high levels of CD150 mRNA and proteins [51]. Both types of lymphomas can sometimes regress after natural infection with wild-type MV (reviewed in [26]). It is likely that these malignancies could be successfully targeted by an oncolytic virus that interacts with CD150 as a cell entry receptor. This hypothesis is supported by observations that MV-Edm can infect metastases and primary tumors in mantle cell lymphoma murine xenografts [67]. Perhaps other cancers that express high levels of CD150 could also be successfully targeted by attenuated MV with the ability to interact with CD150.

CD46 (complement regulatory protein or membrane cofactor protein) is a membrane glycoprotein that serves as a regulator of the complement system. By inhibiting complement activation in host cells, this protein protects cells from complement associated damage [68]. CD46 is also involved in other processes: It interacts with at least seven human pathogens and regulates the adaptive immune response by inducing differentiation of T cells into regulatory T cells $[69,70]$.

According to HPA, CD46 protein is expressed at comparatively high levels in glandular cells of the breast, stomach, and colon as well as in several other cell types. At low levels it is expressed in almost all human cells and tissues [14-16]. CD46 expression protects a cell from complement-dependent cytotoxicity, so expression in a cancer cell promotes escape from immune surveillance and provides the cancer cell with a strong survival advantage [71]. Therefore, advanced cancers are frequently characterized by high levels of CD46 (Table 2). Two studies demonstrate that efficiency of cellular virus entry into and killing of tumor cells correlates with CD46 cell surface protein expression [52,72]. The cell vulnerability to virus infection and syncytia formation has been shown to correlate with the level of CD46 expression. Thus, at a low expression level of CD46, which is typical of normal cells, infection occurs, but intercellular fusion is negligible. However, tumor cells with a higher CD46 expression are much more vulnerable to virus infection along with the formation of syncytia [72].

Based on these observations, CD46 could be included in a list of biomarkers to predict potential tumor response to virotherapy by attenuated MV.

Nectin-4 (also called PVRL4-Poliovirus-Receptor-Like 4) is a transmembrane protein that belongs to a family of $\mathrm{Ca}^{2+}$-independent immunoglobulin-like cell adhesion molecules. It contributes to cell to cell adhesion and intercellular communication [73,74] and serves as a receptor for MV (Table 1, Figure 3A). According to HPA, the nectin-4 protein is expressed at high or medium levels in glandular cells of breast, colon, gall bladder, and stomach as well as in some other cells and tissues [14-16].

Nectin-4 gene expression promotes malignant cells' evasion of growth constraints related to matrix detachment. This gene has been frequently found to be amplified and overexpressed in some solid tumors $[75,76]$. A summary of malignancies in which nectin- 4 has high expression levels is 
presented in Table 2. Most likely, this protein helps MV-Edm to enter a malignant cell. The observation that nectin-4 was specifically used for MV entry into nectin-4 positive cancerous breast and colon cells supports this hypothesis [45]. Therefore, nectin- 4 is another candidate to be included in a list of sensitivity biomarkers for oncolytic attenuated MV.

\section{MV Retargeting for Binding New Cancer-Associated Proteins}

Cellular entry of MV-Edm requires the interaction between viral $\mathrm{H}$ protein and cell surface receptors. In many types of normal cells, expression of CD150, CD46, or nectin-4 is detected. To make the oncolytic virus safer by targeting cancer cells more specifically, it would be beneficial to modify the virus preference for host cell entry. By changing viral $\mathrm{H}$ protein, which is responsible for the virus-receptor interaction, MV-Edm can be retargeted to infect different cells.

The affinity of the receptor for the virus is an important determinant of infectivity and, consequently, infection-induced cell fusion. In this context, affinity is a measure of the strength with which a virus binds to a cellular receptor. The fusion of infected cells with each other depends on this affinity and on the density of receptors on the cell surface, which is a measure of the concentration of receptors in the cell membrane. This density depends on the levels of intracellular expression of the receptor that can be measured. There is a threshold for receptor expression below which cell fusion is ineffective. There is also another threshold for receptor expression, above which there is no further increase in membrane fusion in cell culture $[77,78]$. Because of this non-linear relationship between viral infection-induced cell fusion and the level of expression of the receptor in vivo, it is very important to test any retargeting strategy.

Retargeting can be achieved by inserting genes that encode single-chain fragments of antibodies or other receptor-binding ligands into the viral genome (Figure $3 \mathrm{~A}$ ). This genetic engineering procedure allows for the creation of MV constructs that target a wide range of cancer associated proteins. Several studies describe such virus retargeting modifications (Table 4). The retargeting is a result of genomic changes that enable MV to use different cancer cell associated proteins as cell entry receptors (Table 4 ).

Table 4. Retargeting MV for binding to new receptors.

\begin{tabular}{|c|c|c|c|c|c|}
\hline Blinding to & $\begin{array}{l}\text { Introducing } \\
\text { Property to Bind }\end{array}$ & Effect & $\begin{array}{l}\text { Cell Type or } \\
\text { Malignancy }\end{array}$ & $\begin{array}{l}\text { Model and Type of } \\
\text { Virus Delivery to } \\
\text { Animals }\end{array}$ & Reference \\
\hline \multirow{8}{*}{ None } & \multicolumn{5}{|c|}{$\begin{array}{l}\text { Via fusion of viral } \mathrm{H} \text { protein with epidermal growth factor (EGF) or insulin-like growth factor } 1 \text { (IGF1) } \\
\text { receptor binding domains }\end{array}$} \\
\hline & $\begin{array}{l}\text { EGF or IGF1 } \\
\text { receptors }\end{array}$ & $\begin{array}{l}\text { Infection of EGF or IGF1 } \\
\text { receptor positive and } \\
\text { CD46 negative cells }\end{array}$ & $\begin{array}{l}\text { EGF or IGF1 } \\
\text { receptor positive } \\
\text { cells }\end{array}$ & Cell culture & [79] \\
\hline & \multicolumn{5}{|c|}{ Via fusion of viral $\mathrm{H}$ protein with a single-chain variable fragment (scFv) } \\
\hline & $\begin{array}{l}\text { Carcino-embryonic } \\
\text { antigen (CEA) }\end{array}$ & $\begin{array}{l}\text { Infection of CEA } \\
\text { positive cells }\end{array}$ & CEA-positive cells & Cell culture & {$[80]$} \\
\hline & CD20 & Delayed growth & Fibrosarcoma & $\begin{array}{l}\text { Xenografts; } \\
\text { IP virus delivery }\end{array}$ & [81] \\
\hline & CD38 & $\begin{array}{l}\text { Malignant cells less } \\
\text { tumorigenic, } \\
\text { animal survival } \\
\text { prolonged }\end{array}$ & Multiple myeloma & $\begin{array}{l}\text { Xenografts; } \\
\text { construct premixed } \\
\text { with tumor cells } \\
\text { before implantation }\end{array}$ & [82] \\
\hline & \multicolumn{5}{|c|}{ Via fusion of viral $\mathrm{H}$ protein with echistatin, which is a 49-residue peptide from family of disintegrins } \\
\hline & $\begin{array}{l}\text { Integrin } \\
\text { alpha(v)beta3 }\end{array}$ & $\begin{array}{l}\text { Tumor regressed or } \\
\text { stabilized }\end{array}$ & Multiple myeloma & $\begin{array}{l}\text { Xenografts; } \\
\text { IT virus delivery }\end{array}$ & [83] \\
\hline
\end{tabular}


A proof of the possibility of redirection of MV cell targeting was obtained with engineered MV-Edm based constructs targeting three cancer associated proteins: EGF, IGF1 [79], and carcinoembryonic antigen (CEA) [80]. In cell cultures, MV-Edm constructs can successfully target, infect, and destroy corresponding malignant cells that overexpress one of these three proteins.

The retargeting genetic engineering approach was further used for creation of viral constructs with ability to recognize two other membrane associated proteins. One was phosphoprotein CD20 [81], which is expressed in normal hematopoietic cells and overexpressed in B-cell lymphomas, leukemias and some other malignancies (Table 5). Another was glycoprotein CD38 [82], expression of which characterizes immune cells and overexpression characterizes NK/T-cell lymphomas, lymphocytic leukemias, multiple myelomas and other malignancies (Table 5). Antitumor effects of both constructs were tested in animal xenografts. Implanted CD20-positive fibrosarcomas demonstrated delayed growth after IP construct delivery, while CD38-positive multiple myeloma cells became less tumorigenic after premixing with the corresponding viral construct.

Table 5. Expression of retargeted measles virus receptors in normal and malignant cells.

\begin{tabular}{|c|c|c|c|}
\hline Receptor Name & Alternative Name & \multicolumn{2}{|c|}{ Expression } \\
\hline $\begin{array}{l}\text { CEA } \\
\text { glyco-proteins }\end{array}$ & $\begin{array}{l}\text { Carcinoembryonic } \\
\text { antigen-related cell } \\
\text { adhesion molecules }\end{array}$ & $\begin{array}{l}\text { High or moderate in gastric, } \\
\text { colorectal, lung ovarian, breast, } \\
\text { and cervical cancers [84] }\end{array}$ & $\begin{array}{l}\text { Different subfamily members } \\
\text { expressed to different degrees } \\
\text { in hematopoietic cells, } \\
\text { glandular cells of } \\
\text { colon, etc. [14-16] }\end{array}$ \\
\hline CD133 & Prominin-1 (PROM1) & $\begin{array}{l}\text { High in leukemias [85], } \\
\text { gliomas [86,87], colorectal, } \\
\text { prostate, endometrial, } \\
\text { pancreatic and thyroid } \\
\text { cancers [14-16], and non-small } \\
\text { cell lung cancers [88]. } \\
\text { Levels in gliomas [87] and } \\
\text { non-small cell lung cancers [88] } \\
\text { are negatively correlated with } \\
\text { patient survival [87] }\end{array}$ & $\begin{array}{l}\text { High in glandular cells of gall } \\
\text { bladder, endometrium, cervix } \\
\text { and uterus [14-16]. } \\
\text { Also expressed on the surfaces } \\
\text { of hematopoietic stem } \\
\text { cells [89], epithelial progenitor } \\
\text { cells [90], and neural and glial } \\
\text { stem cells [86] }\end{array}$ \\
\hline CD20 & $\begin{array}{l}\text { MS4A1, B1, Bp35, CVID5, } \\
\text { LEU-16, MS4A2, S7, } \\
\text { membrane spanning } \\
\text { 4-domains A1 }\end{array}$ & $\begin{array}{l}\text { Frequently high in B-cell } \\
\text { lymphomas [91], B-cell } \\
\text { leukemias [92], and melanoma } \\
\text { stem cells [93]. Less frequent } \\
\text { in Hodgkin's lymphoma [94], } \\
\text { myeloma [95], } \\
\text { and thymoma [96] }\end{array}$ & $\begin{array}{l}\text { Low and moderate expression } \\
\text { in white and red pulp in } \\
\text { spleen, hematopoietic cells of } \\
\text { bone marrow, lymphoid } \\
\text { tissues of appendix. and } \\
\text { other tissues [14-16] }\end{array}$ \\
\hline CD38 & $\begin{array}{l}\text { Cyclic ADP ribose } \\
\text { hydrolase }\end{array}$ & $\begin{array}{l}\text { High in chronic lymphocytic } \\
\text { leukemia }[97,98] \\
\text { in NK/T-cell lymphomas [99], } \\
\text { and in multiple myeloma [100] }\end{array}$ & $\begin{array}{l}\text { High in large spectrum of } \\
\text { immune cells as well as } \\
\text { glandular cells of prostate and } \\
\text { seminal vesicles [14-16] }\end{array}$ \\
\hline $\begin{array}{l}\text { Epidermal growth factor } \\
\text { receptor } 2 \text { (EGFR2) }\end{array}$ & $\begin{array}{l}\text { Receptor } \\
\text { tyrosine-protein kinase, } \\
\text { ErbB-2, HER2/neu, } \\
\text { ERBB2, CD340 }\end{array}$ & $\begin{array}{l}\text { Frequently highly } \\
\text { overexpressed in malignancies } \\
\text { including breast [101], } \\
\text { stomach [102], } \\
\text { endometrial [103,104], ovarian, } \\
\text { uterine [105] colorectal [106], } \\
\text { thyroid [107], urothelial [108] }\end{array}$ & $\begin{array}{l}\text { Medium levels in glandular } \\
\text { cells of appendix, breast, } \\
\text { and cervix, myocytes, } \\
\text { respiratory epithelium, } \\
\text { and urothelial cells [14-16] }\end{array}$ \\
\hline
\end{tabular}


Table 5. Cont.

\begin{tabular}{|c|c|c|c|}
\hline \multirow{2}{*}{ Receptor Name } & \multirow{2}{*}{ Alternative Name } & \multicolumn{2}{|c|}{ Expression } \\
\hline & & In Malignancies & In Normal Cells and Tissues \\
\hline $\begin{array}{l}\text { Insulin-like growth } \\
\text { factor receptor (IGF1R) }\end{array}$ & IGF-1 receptor & $\begin{array}{l}\text { High in lymphomas, thyroid, } \\
\text { liver, pancreatic, and many } \\
\text { other cancers [14-16] }\end{array}$ & $\begin{array}{l}\text { Low level of expression in } \\
\text { bone marrow hematopoietic } \\
\text { cells, respiratory cells, and } \\
\text { glandular cells of } \\
\text { gallbladder [14-16] }\end{array}$ \\
\hline $\begin{array}{l}\text { Folate receptor } 1 \\
\text { (FOLR1) }\end{array}$ & $\begin{array}{l}\text { Folate receptor alpha, } \\
\text { Glutamate } \\
\text { carboxypeptidase II } \\
\text { (GCPII), and folate } \\
\text { hydrolase } 1\end{array}$ & $\begin{array}{l}\text { High in ovarian } \\
\text { cancers [14-16]; particularly } \\
\text { strong and frequent expression } \\
\text { of mRNA observed in } \\
\text { non-mucinous ovarian } \\
\text { cancers [109] }\end{array}$ & $\begin{array}{l}\text { Medium levels in brain, lung, } \\
\text { and salivary gland } \\
\text { tissues [14-16] }\end{array}$ \\
\hline $\begin{array}{l}\text { Prostate specific } \\
\text { membrane antigen, } \\
\text { (PSMA) }\end{array}$ & & $\begin{array}{l}\text { High expression in malignant } \\
\text { prostate cells [110] }\end{array}$ & $\begin{array}{l}\text { High expression in prostate } \\
\text { tissues [110] }\end{array}$ \\
\hline Urokinase receptor & $\begin{array}{l}\text { UPA, UPAR, CD87, } \\
\text { PLAUR }\end{array}$ & $\begin{array}{l}\text { Infrequently expressed in } \\
\text { malignant cells [14-16] }\end{array}$ & $\begin{array}{l}\text { High in bone marrow, } \\
\text { lymphoid tissues, neutrophils, } \\
\text { and respiratory epithelial cells } \\
\text { of the nasopharynx and } \\
\text { bronchus }\end{array}$ \\
\hline
\end{tabular}

An alternative approach for MV-Edm retargeting to cell surface antigens of choice was developed by using cystine knot proteins instead of single chain antibodies $[83,111]$. These short proteins are capable of binding integrins, which are frequently overexpressed by a tumor's vascular endothelium. The retargeted virus was able to infect and kill cancer cells that expressed the integrins, including glioblastoma, medulloblastoma, melanoma and others [111]. Most importantly, when injected intravenously into animals carrying glioblastoma, the construct reached the tumor and caused cytopathic effects [111].

The introduction of the ability to bind new viral receptors may be accompanied by blinding to the natural receptors CD150 and CD46. This blinding reduces the potential infection of CD150and CD46-positive normal cells because CD150 is expressed on the surface of normal hematopoietic stem and progenitor cells [36-38], while high CD46 expression characterizes glandular cells of many organs [14-16]. Blinding increases the safety of viral construct application because MV infection is usually detrimental to host healthy cells.

Blinding to specific receptors became possible after identification of residues in $\mathrm{H}$ protein that are necessary for CD150 or CD46 binding [112]. Multiple retargeting strategies have been used to modify the MV-Edm genome. These include the genomic introduction of genes encoding single-chain antibody fragments (scFv), cystine knot proteins, and designed ankyrin repeat proteins (DARPins). The antibody fragment strategy allowed the targeting of various cancer associated proteins such as CD38, epidermal growth factor receptor 1 [113,114], folate receptor 1 [109], prostate specific membrane antigen [110], human epidermal growth factor receptor 2 (HER2/neu) [77], prominin or CD133 [115,116], and plasminogen activator urokinase receptor $[117,118]$. The cystine knot strategy targeted integrins, which are highly expressed in glioblastomas, medulloblastomas and melanomas [111]. Finally, the DARPin strategy targeted ovarian carcinomas that express $\mathrm{HER}_{2} /$ neu or/and epithelial cell adhesion molecule (EpCAM) [119,120], along with EGFR-expressing glioblastomas [121]. To reduce bystander killing of receptor-expressing normal cells, a gene that encodes an engineered viral fusion protein and that can be processed by tumor-associated matrix metalloproteases was added to the virus genome. This introduction made the targeting of the virus to tumor cells very specific [121]. All of these new constructs were tested in cell lines and some in xenograft models of human malignancies, and demonstrated strong or moderate antitumor effects (Table 6). 
Table 6. MV receptor blinding and retargeting.

\begin{tabular}{|c|c|c|c|c|c|}
\hline Blinding to & $\begin{array}{l}\text { Introducing } \\
\text { Property to Bind }\end{array}$ & Effect & $\begin{array}{l}\text { Cell Type or } \\
\text { Malignancy }\end{array}$ & $\begin{array}{l}\text { Model; Route } \\
\text { of Virus } \\
\text { Delivery to } \\
\text { Animals }\end{array}$ & Reference \\
\hline \multirow{12}{*}{$\begin{array}{l}\text { CD150/SLAM } \\
\text { and CD46 }\end{array}$} & \multicolumn{5}{|c|}{ Via fusion of viral $\mathrm{H}$ protein with scFv } \\
\hline & CD38 or EGFR & $\begin{array}{l}\text { Tumor stabilized; } \\
\text { animal survival } \\
\text { prolonged }\end{array}$ & $\begin{array}{l}\text { CD38 or EGFR } \\
\text { positive cancers }\end{array}$ & $\begin{array}{l}\text { Xenografts; IT } \\
\text { or IV }\end{array}$ & {$[113,114]$} \\
\hline & $\begin{array}{l}\text { Folate receptor } 1 \\
\text { (FOLR1) }\end{array}$ & $\begin{array}{l}\text { Biodistribution more } \\
\text { specific towards } \\
\text { malignant tissues; } \\
\text { tumor stabilized; } \\
\text { animal survival } \\
\text { prolonged }\end{array}$ & Ovarian cancer & Xenografts; IV & [109] \\
\hline & $\begin{array}{l}\text { Prostate specific } \\
\text { membrane antigen, } \\
\text { (PSMA) }\end{array}$ & $\begin{array}{l}\text { Tumor stabilized; } \\
\text { animal survival } \\
\text { prolonged }\end{array}$ & Prostate cancer & Xenografts; IT & [122] \\
\hline & HER2 protein & $\begin{array}{l}\text { Malignant cells } \\
\text { infected in vitro, } \\
\text { tumor regressed, } \\
\text { animal survival } \\
\text { prolonged }\end{array}$ & Ovarian cancer & Xenografts; IP & {$[77,78]$} \\
\hline & $\begin{array}{l}\text { CD133, Prominin1 } \\
\text { (PROM1) }\end{array}$ & $\begin{array}{l}\text { Tumor formation } \\
\text { inhibited; animal } \\
\text { survival prolonged }\end{array}$ & $\begin{array}{l}\text { Glioblastoma, lung } \\
\text { metastases of colon } \\
\text { cancer and } \\
\text { hepatocellular } \\
\text { carcinoma }\end{array}$ & $\begin{array}{l}\text { Xenografts; IT } \\
\text { or IV }\end{array}$ & {$[115,116]$} \\
\hline & Urokinase receptor & $\begin{array}{l}\text { Delayed } \\
\text { development of lung } \\
\text { metastases, animal } \\
\text { survival prolonged }\end{array}$ & Breast cancer & $\begin{array}{l}\text { Syngeneic and } \\
\text { xenografts; IV }\end{array}$ & {$[117,118]$} \\
\hline & \multicolumn{5}{|c|}{ Via fusion of viral $\mathrm{H}$ protein with cystine knot proteins } \\
\hline & Integrins & $\begin{array}{l}\text { Malignant cells } \\
\text { killed in vitro; } \\
\text { cytopathic effects } \\
\text { produced in vivo }\end{array}$ & $\begin{array}{l}\text { Glioblastoma, } \\
\text { medullo-blastoma, } \\
\text { melanoma }\end{array}$ & $\begin{array}{l}\text { Glioblastoma } \\
\text { xenografts; IV }\end{array}$ & [111] \\
\hline & \multicolumn{5}{|c|}{ Via fusion of viral H protein with designed ankyrin repeat proteins (DARPin) } \\
\hline & $\begin{array}{l}\text { Bispecific binding } \\
\text { to HER2/neu, } \\
\text { and/or EpCAM }\end{array}$ & $\begin{array}{l}\text { Animal survival } \\
\text { significantly } \\
\text { prolonged, tumor } \\
\text { burden reduced }\end{array}$ & Ovarian cancer & Xenografts; IT & {$[119,120]$} \\
\hline & EGFR & $\begin{array}{l}\text { Malignant cells } \\
\text { killed in vitro }\end{array}$ & $\begin{array}{l}\text { Glioblastoma } \\
\text { multiforme }\end{array}$ & Cell lines & [121] \\
\hline
\end{tabular}

\section{SeV as an Oncolytic Agent}

$\mathrm{SeV}$ causes respiratory infections in mice and other rodents (Box 2). However, it is not associated with any human disease and can be a safe oncolytic agent. Safety of $\mathrm{SeV}$ for humans, including small children, has been confirmed experimentally. The virus in the form of nasal drops has been tested as a vaccine against human parainfluenza virus type 1 (HPIV-1), which causes respiratory symptoms in humans. Testing in adults and children demonstrated that experimental administration of wild type SeV triggered production of neutralizing antibodies towards HPIV-1 and was well tolerated [123,124]. Replication competent $\mathrm{SeV}$ vector showed an excellent safety profile in a stage 1 clinical trial [125] and is considered highly suitable as an antigen delivery tool [126,127]. Pre-existing anti-vector immunity didn't affect the immunogenicity of SeV-delivered antigens [126]. 
Box 2. Sendai Virus (SeV).

Taxonomy: The virus belongs to the genus Respirovirus within the family Paramyxoviridae [23].

Host: The virus causes respiratory infections in mice, hamsters, guinea pigs, rats, and other rodents [128].

Genome: SeV has single-stranded, negative-sense, non-segmented RNA genome that is $~ 15 \mathrm{~K}$ nucleotides long [129].

Virion: $\mathrm{SeV}$ is an enveloped virus with a lipid membrane.

Proteins: Nucleoprotein $(\mathrm{N})$, phosphoprotein $(\mathrm{P})$, matrix protein $(\mathrm{M})$, fusion protein $(\mathrm{F})$, hemagglutininneuraminidase $(\mathrm{HN})$, large protein $(\mathrm{L})$, and nonstructural proteins collectively referred as C-proteins $\left(\mathrm{C}^{\prime}, \mathrm{C}, \mathrm{Y} 1\right.$, $\mathrm{Y} 2, \mathrm{~V}, \mathrm{~W})$ that are translated from an alternative RNA transcript of the P gene [129].

Wild-type SeV can replicate and productively infect a large spectrum of malignant cells ex vivo (Table 7). A pilot study demonstrated that some canine mastocytomas can be eradicated with the help of SeV injections [130]. However, the virus is infectious and immunosuppressive for laboratory rodents. Therefore, for studying SeV oncolytic properties in a rodent model, a set of viral constructs that are nonpathogenic for experimental mice was created. These constructs were tested in animals bearing a variety of human xenograft tumors including sarcoma, melanoma, pancreas, colon, hepatocellular and prostate carcinomas. The SeV constructs promoted growth suppression or even complete tumor eradication of these malignancies [131-134], and elimination of established brain tumors [135].

In addition, $\mathrm{UV}$ - inactivated $\mathrm{SeV}$ virions have immune-stimulating properties: In syngeneic mice they promote immunomodulated tumor regression of colon [136,137], bladder [138], and kidney [139] cancers. In murine xenografts these virions contribute to the eradication of human prostate cancer [140].

Table 7. Cancer cell-lines susceptible to SeV infection.

\begin{tabular}{lll}
\hline \multicolumn{1}{c}{ Cell Line } & \multicolumn{1}{c}{ Type of Malignancy } & Reference \\
\hline Human origin & & {$[141]$} \\
\hline MCF7 & Breast carcinoma & {$[142]$} \\
\hline HeLa & Cervical carcinoma & {$[13]$} \\
\hline CaCo2 & Colon carcinoma & {$[143]$} \\
\hline U118 & Glioblastoma & {$[144]$} \\
\hline U87MG & Most likely, human glioma & {$[142,145,146]$} \\
\hline Hep G2 & Hepatic carcinoma & {$[146,147]$} \\
\hline Huh7 & & {$[142,148-150]$} \\
\hline A549 & Lung carcinoma & {$[13]$} \\
\hline Calu-3 & & {$[149]$} \\
\hline U937 & Histiocytic lymphoma & {$[149,151]$} \\
\hline Namalwa & Burkitt's lymphoma & {$[152]$} \\
\hline PC-3 & Prostate carcinoma derived from metastatic site in bone & \\
\hline DU145 & Prostate carcinoma derived from metastatic site in brain & {$[142]$} \\
\hline Murine origin & &
\end{tabular}

So far, SeV has not been widely tested in clinical settings. An attempt to treat one case of human leukemia with a set of viruses, including SeV, was undertaken in 1964 at the Clinical Research Center of University Hospitals of Cleveland. Short-term remission in one patient affected by acute leukemia was observed after IV virus injection [153]. A few patients affected by various malignancies were treated with intradermally or intratumorally injected SeV in Moscow (Russia) in the 1990s. In a small fraction 
of patients treated with the virus, primary tumors and metastases disappeared, even when virotherapy was a monotherapy. These patients experienced a pronounced long-term remission that sometimes lasted more than 5-10 years [154].

\section{SeV receptors}

$\mathrm{SeV}$, as a representative of respiratory viruses, uses mainly molecules containing sialic acid residues (sialylated proteins as well as lipids) as cell entry receptors. Thus, bovine sialoglycoprotein (GP2) [155], human asialoglycoprotein receptor (ASGR1) [145,156], and sialoglycoprotein (glycophorin A (GYPA)) [157] bind SeV with high affinity and could act as virus receptors. Glycans (polysaccharides) attached to lipids could also bind $\mathrm{SeV}$ and serve as entry receptors. For example, two carbohydrates, sialyl Lewis-x and VIM-2, when attached to lipids, are capable of binding to SeV with high affinity [158]. Other SeV receptors are represented by gangliosides (Table 8, Figure 4).

Table 8. Cell entry receptors for sendai virus.

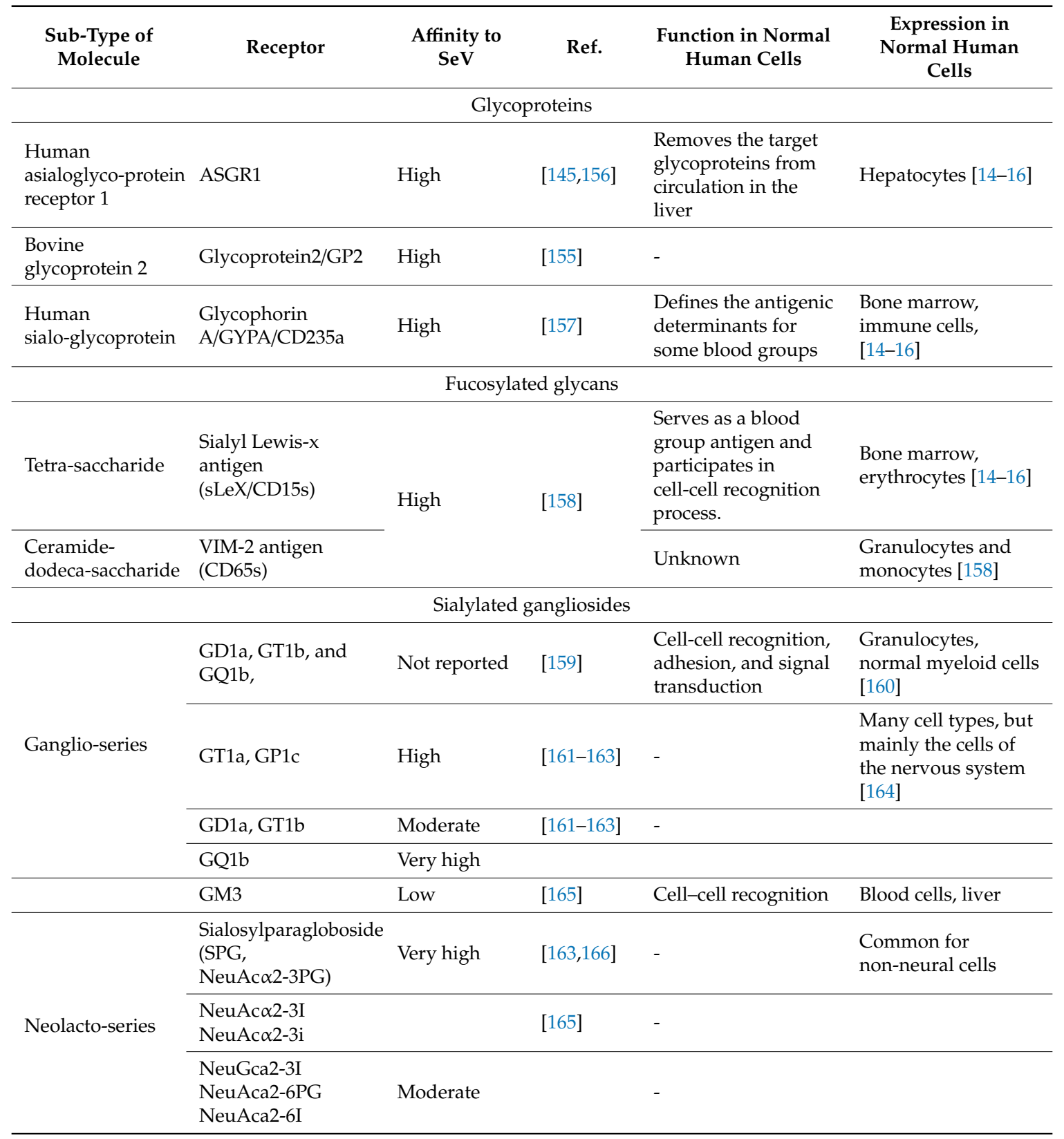




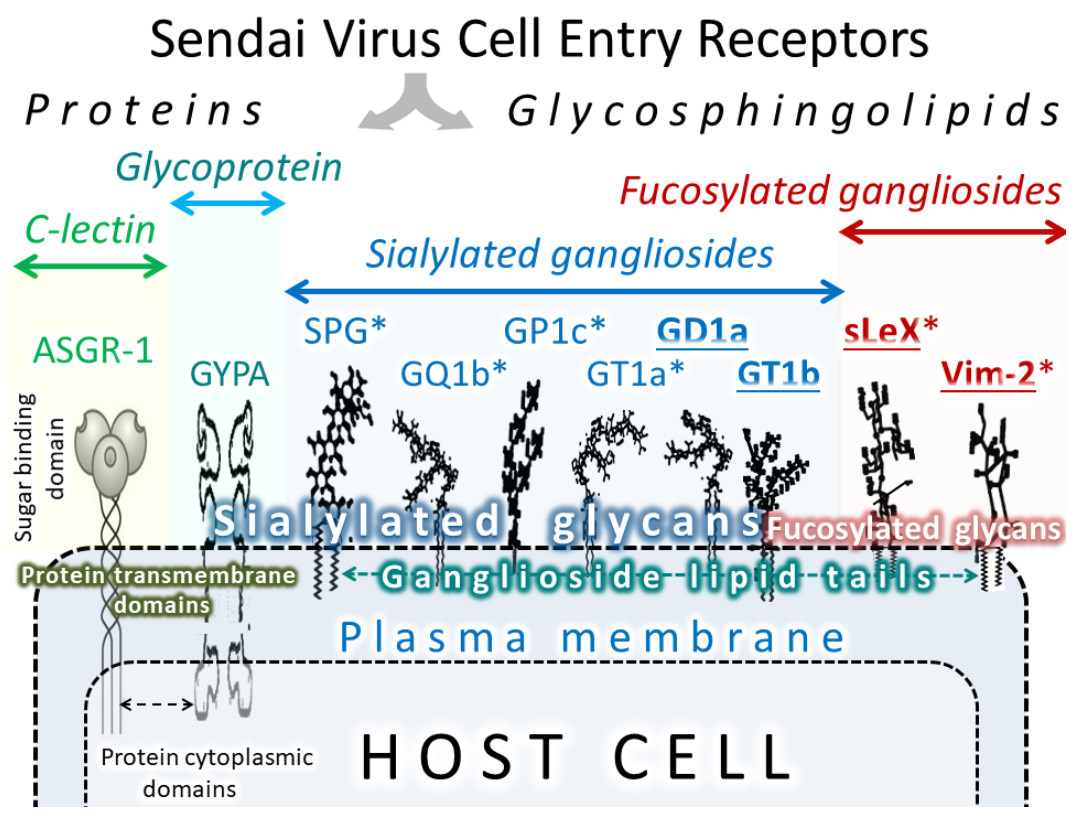

Figure 4. SeV receptors. The names of receptors with known high binding affinity to the virus are marked with stars. The names of receptors that are overexpressed in some malignancies are in bold and underlined.

Sialyl-Lewis $\mathrm{X}$ antigen (sLeX), also called stage-specific embryonic antigen 1 or cluster of differentiation 15 (CD15s), is one of the most important blood group antigens. It is a tetrasaccharide and may be attached to a lipid or a protein [92-94]. SLeX demonstrated high binding affinity to SeV when attached to sphingolipid [158]. However, whether sLeX can bind with a virus when attached to a protein is unknown. Expression of sLeX correlates significantly with malignant cell invasion, tumor recurrence and overall patient survival for an extremely broad range of cancers (Table 9) (reviewed in [167]). It is likely that sLeX positive cancer cells use the leukocyte adhesion pathway for extravasation, which facilitates tumor invasion and spread. Tumors with high expression of this antigen can bind $\mathrm{SeV}$ and are potential candidates for $\mathrm{SeV}$ therapy.

Table 9. Receptors for $\mathrm{SeV}$ and their expression in malignancies.

\begin{tabular}{|c|c|c|c|}
\hline Receptor & Malignancy/Effect of Receptor Expression & Ref. & $\begin{array}{l}\text { Monoclonal AB } \\
\text { Availability }\end{array}$ \\
\hline $\begin{array}{l}\text { Human } \\
\text { asialoglyco-protein } \\
\text { receptor } 1\end{array}$ & $\begin{array}{l}\text { High expression in liver cancer and occasionally } \\
\text { moderate expression in gliomas, renal, pancreatic, } \\
\text { colorectal, and ovarian cancers }\end{array}$ & {$[14-16]$} & Two variants [14-16] \\
\hline \multirow{8}{*}{$\begin{array}{l}\text { Sialyl-Lewis }{ }^{\mathrm{x}} \\
\text { Antigen (sLeX/CD15) }\end{array}$} & $\begin{array}{l}\text { Non-small cell lung cancer/enhances post-operative } \\
\text { recurrence }\end{array}$ & {$[168,169]$} & \multirow{8}{*}{ Many variants [170] } \\
\hline & Lung cancer, distant metastases & [171] & \\
\hline & $\begin{array}{l}\text { Colorectal cancer/promotes liver metastases, decreases } \\
\text { time of disease-free survival }\end{array}$ & [172-174] & \\
\hline & Gastric cancers/decreases patient survival time & {$[175,176]$} & \\
\hline & Breast cancer/decreases patient survival time & [177-179] & \\
\hline & Prostate tumor/promotes bone metastases & [180-182] & \\
\hline & $\begin{array}{l}\text { Cell lines of variable origin/high expression enhances } \\
\text { adhesion of malignant cells to vascular endothelium }\end{array}$ & [183] & \\
\hline & $\begin{array}{l}\text { Variable cancers/high expression related to lymphatic } \\
\text { invasion, venous invasion, T stage, } \mathrm{N} \text { stage, } \mathrm{M} \text { stage, } \\
\text { tumor stage, recurrence, and overall patient survival }\end{array}$ & Review [167] & \\
\hline
\end{tabular}


Table 9. Cont.

\begin{tabular}{llll}
\hline \multicolumn{1}{c}{ Receptor } & \multicolumn{1}{c}{ Malignancy/Effect of Receptor Expression } & \multicolumn{1}{c}{ Ref. } & \multicolumn{1}{c}{$\begin{array}{c}\text { Monoclonal AB } \\
\text { Availability }\end{array}$} \\
\hline $\begin{array}{l}\text { VIM-2 antigen } \\
\text { (CD65s) }\end{array}$ & Acute myeloblastic leukemias & {$[160,184,185]$} & One variant [170] \\
\hline \multirow{2}{*}{ GD1a } & Breast cancer stem cells & {$[186]$} & Many variants [170] \\
\cline { 2 - 3 } & Castration-resistant prostate cancer cells & {$[187]$} & \multirow{2}{*}{ Three variants [170] } \\
\hline GT1b & $\begin{array}{l}\text { Brain metastases from colon, renal, lung, esophagus, } \\
\text { pancreas, and mammary carcinomas }\end{array}$ & {$[188]$} & One variant [189] \\
\hline \multirow{2}{*}{ SPG } & Castration-resistant prostate cancer cells & {$[187]$} & {$[189,190]$} \\
\cline { 2 - 3 } & Lymphoid leukemia cells & & \\
\hline
\end{tabular}

VIM-2 antigen, (also called cluster of differentiation 65 sialylated [CD65s]), is a carbohydrate that can be attached to a sphingolipid and has high binding affinity to SeV [158]. VIM-2 is expressed on surfaces of granulocytes, normal myeloid cells, and cells of acute myeloblastic leukemias [160,184]. Its expression is critically important for extravascular infiltration of acute myeloid leukemia cells [185]. Perhaps myeloblastic leukemias that are resistant to modern therapies could be treated with SeV.

Gangliosides are sialic acid-containing glycosphingolipids that are capable of binding SeV. It has been demonstrated that these molecules can serve as $\mathrm{SeV}$ cell entry receptors (Table 7). There is substantial evidence that at least three of them, SPG, GD1a, and GT1b, are highly involved in carcinogenesis and metastasis (Table 8). High expression of SPG characterizes lymphoid leukemia cells $[189,190]$ and GD1a characterizes breast cancer stem cells [186]. High expression of both SPG and GD1a was found in castration-resistant prostate cancer cells [187]. High expression of GT1b is universally associated with brain metastases that originate from an extremely broad spectrum of cancers [188].

GM3, GD1a, and GT1b expression in a cell might be less predictive of SeV infectability than the expression of other molecules (104). Therefore, sLeX, VIM-2 and SPG are potential biomarkers for identification of cancers that could be efficiently infected by the virus. However, it is likely that new receptors for the $\mathrm{SeV}$ virus will be identified in the future.

Cellular expression of gangliosides is currently evaluated using glycan-specific antibody-based methods. These methods are not always suitable for large-scale screenings. Moreover, anti-ganglioside monoclonal antibodies are not always commercially available [170]. Therefore, indirect measurement of ganglioside expression through expression levels of fucosyltransferases and glycosyltransferases, which are enzymes that finalize ganglioside synthesis, represents an alternative. Expression of these enzymes and production of gangliosides are highly correlated [187]. At least five representatives of the fucosyltransferase family and six representatives of the glycosyltransferase family are responsible for synthesis of gangliosides that could serve as $\mathrm{SeV}$ receptors (Table S1). All these proteins are frequently overexpressed in various tumors and their expression levels correlate with tumor metastatic status and duration of patient survival (Table S2). These enzymes deserve to be studied as potential biomarkers of the oncolytic infectivity of SeV.

\section{Potential Problems of Virus Delivery and Retargeting}

\subsection{Preexisting Immunity}

One potential problem of MV and $\mathrm{SeV}$ applications as oncolytic agents is pre-existing antiviral immunity, which might affect systemic tumor-targeted viral delivery and intratumoral infection spread. For MV, this immunity is a result of childhood vaccination or measles disease. For SeV, previous infection with human parainfluenza virus type 1 (HPIV1) causes this immunity to the extent that the two viruses share some antigenic determinants [123,124]. It has been shown for SeV [191] and for MV [192] that prevalence of specific neutralizing antibodies against these viruses in adult human 
population is extremely variable. It is still largely unknown to what degree preexisting immunity may decrease the effect of oncolytic virotherapy. However, some virus delivery approaches discussed in the next section might help minimize this problem.

\subsection{Virus Transportation and Tumor Delivery}

Oncolytic virus constructs can be preloaded to specific cell carriers ex vivo and subsequently, after intravenous injection, transported to tumor sites in vivo [193,194]. Hypothetically, dendritic cells (DCs) could serve as oncolytic virus transportation vehicles. These cells can be infected by both vaccine and wild type strains of MV [195] via the CD150 cell receptor [196]. MV-infected DCs have higher motility toward the epithelial cell layer compared to uninfected ones. Therefore, MV infection enables rapid trafficking of the virus toward epithelial cells [197] and, perhaps, to other tissues including malignant tumors and metastases. Blinding of MV constructs to CD150 increases virus safety but might decrease efficiency of virus tumor delivery through its natural cell carriers such as DCs. SeV can also infect DCs [198] and can transform them into activated mature cells that efficiently contribute to tumor clearance and animal survival [199]. It is not known if MV-Edm or SeV-loaded DCs could ensure viral antibody protection and efficient tumor delivery; however, it is likely. Researchers should not ignore this hypothetical natural route of virus delivery to the tumor. For example, reovirus-loaded DCs protect the virus from neutralizing antibodies and facilitate viral infection of transplanted melanoma cells in model animals $[200,201]$. The ability of DCs to migrate after viral infection may facilitate viral tumor delivery without detection by host pre-existing immunity. Consequently, this ability might be a great asset for oncolytic virotherapy.

\section{Additional Factors Determining Cell Sensitivity to Viruses}

The presence of viral receptors is a necessary but not sufficient condition for a cell to be vulnerable to viral infection. Despite the presence of the receptors, a malignant cell can be resistant to the virus when the functioning of the IFN pathway is not impaired [202]. If the pathway is active in the cancer cell and the IFN signal is transduced from the cell surface to its nucleus, the cell can be protected from viral infection.

The cells' ability to activate constitutively expressed genes of the IFN response pathway (ISGs) was the main prognostic factor for detection of carcinomas resistant to MV-Edm. Virus resistance of ovarian carcinomas and gliomas was linked to characteristic expression patterns of 22 ISGs [28]. Similar results were obtained for other malignancies; the sensitivity of melanoma cells to attenuated MV was associated with their response to type I IFN, even though MV receptor levels were the same among the tested cells [203].

The absence of certain proteases is another reason for the inability of the host cell to produce infectious virus. Expression of type II transmembrane serine proteases (TTSPs) by a cell is critical for the proteolytic activation of paramyxovirus F-proteins. Furin serves as an F-protein activating protease for MV [6] while other proteases such as PSB2 [7-9], PRSS1 [10], PLG [11], F10 [12], and TMPRSS2 [13]) serve a similar function for SeV. A host cell that does not express high enough levels of TTSPs can produce only noninfectious virions, rather than infectious virus particles. Expression patterns of TTSPs are variable among malignant cells and some cancers' progression has been shown to relate to alteration of these patterns [204]. Therefore, in some cancer cells that express paramyxovirus F-protein activating TTSPs, the virus can undergo multiple rounds of infection, whereas in other cells which do not express these proteases, the virus can undergo only one, if any, rounds of infection.

In addition to those listed above, there are probably many more genes and proteins that affect the vulnerability of cancer cells to viral infection. Therefore, more research is needed to determine the target tumor cell pathways responsible for productive viral replication, post-replication processing, assembly, and budding of virions. 


\section{Conclusions}

The cell entry receptors of oncolytic paramyxoviruses are represented by different types of molecules such as proteins and glycans. The molecules that serve as viral receptors for attenuated MV and $\mathrm{SeV}$ have extremely variable expression patterns in malignancies. A reliable predictive model for categorization of tumor cells according to their susceptibility to oncolytic virus infection requires many input parameters, which include but are not limited to expression patterns of viral receptors. Most likely, gene signatures of several immune-related genes such as IRGs and certain type II transmembrane serine proteases may serve as useful input parameters for predictive models. The creation and verification of a multi-parameter predictive model should have measurable therapeutic benefits for oncolytic virotherapy.

Supplementary Materials: The following are available online at http://www.mdpi.com/2072-6694/12/12/3659/s1, Table S1: Processing transferases for Sendai virus receptors; Table S2: Overexpression of processing transferases for Sendai virus receptors in malignancies.

Funding: This work was supported by the Intramural Research Programs of the National Library of Medicine (S.A.S.).

Acknowledgments: We thank Peter Chumakov for suggesting the topic for this review and Judith Miller and Timofey Spiridonov for careful reading of this manuscript and numerous constructive suggestions.

Conflicts of Interest: The authors declare no conflict of interest. Olga V. Matveeva belong to a company (Sendai Viralytics LLC). The funders had no role in the design of the study; in the collection, analyses, or interpretation of data; in the writing of the manuscript, or in the decision to publish the results.

\section{Abbreviations}

$\begin{array}{ll}\text { CEA } & \text { Carcinoembryonic antigen } \\ \text { EGF } & \text { Epidermal growth factor } \\ \text { EGFR } & \text { Epidermal growth factor receptor } \\ \text { FOLR1 } & \text { Folate receptor 1 } \\ \text { HER2/neu } & \text { Tyrosine-protein kinase erbB-2 (human epidermal growth factor receptor 2) } \\ \text { IFN } & \text { Interferon } \\ \text { IP } & \text { Intraperitoneal delivery } \\ \text { IT } & \text { Intratumoral delivery } \\ \text { IV } & \text { Intravenous delivery } \\ \text { MV } & \text { Measles virus } \\ \text { PVRL4 } & \text { Poliovirus-receptor-like 4, molecule (nectin-4) } \\ \text { SeV } & \text { Sendai virus } \\ \text { SLAM/SLAMF1/CD150 } & \text { Signaling lymphocytic activation molecule 1 } \\ \text { SPG } & \text { Sialosylparagloboside }\end{array}$

\section{References}

1. Kaufman, H.L.; Kohlhapp, FJ.; Zloza, A. Oncolytic viruses: A new class of immunotherapy drugs. Nat. Rev. Drug Discov. 2015, 14, 642-662. [CrossRef]

2. Marelli, G.; Howells, A.; Lemoine, N.R.; Wang, Y. Oncolytic Viral Therapy and the Immune System: A Double-Edged Sword Against Cancer. Front. Immunol. 2018, 9, 866. [CrossRef]

3. Stetson, D.B.; Medzhitov, R. Antiviral defense: Interferons and beyond. J. Exp. Med. 2006, 203, 1837-1841. [CrossRef]

4. Negishi, H.; Taniguchi, T.; Yanai, H. The Interferon (IFN) Class of Cytokines and the IFN Regulatory Factor (IRF) Transcription Factor Family. Cold Spring Harb. Perspect. Biol. 2017. [CrossRef]

5. Katsoulidis, E.; Kaur, S.; Platanias, L.C. Deregulation of interferon signaling in malignant cells. Pharmaceuticals 2010, 3, 406-418. [CrossRef]

6. Watanabe, M.; Hirano, A.; Stenglein, S.; Nelson, J.; Thomas, G.; Wong, T.C. Engineered serine protease inhibitor prevents furin-catalyzed activation of the fusion glycoprotein and production of infectious measles virus. J. Virol. 1995, 69, 3206-3210. [CrossRef] 
7. Tashiro, M.; Yokogoshi, Y.; Tobita, K.; Seto, J.T.; Rott, R.; Kido, H. Tryptase Clara, an activating protease for Sendai virus in rat lungs, is involved in pneumopathogenicity. J. Virol. 1992, 66, 7211-7216. [CrossRef] [PubMed]

8. Kido, H.; Niwa, Y.; Beppu, Y.; Towatari, T. Cellular proteases involved in the pathogenicity of enveloped animal viruses, human immunodeficiency virus, influenza virus A and Sendai virus. Adv. Enzyme Regul. 1996, 36, 325-347. [CrossRef]

9. Chen, Y.; Shiota, M.; Ohuchi, M.; Towatari, T.; Tashiro, J.; Murakami, M.; Yano, M.; Yang, B.; Kido, H. Mast cell tryptase from pig lungs triggers infection by pneumotropic Sendai and influenza A viruses. Purification and characterization. Eur. J. Biochem. 2000, 267, 3189-3197. [CrossRef] [PubMed]

10. Le, T.Q.; Kawachi, M.; Yamada, H.; Shiota, M.; Okumura, Y.; Kido, H. Identification of trypsin I as a candidate for influenza A virus and Sendai virus envelope glycoprotein processing protease in rat brain. Biol. Chem. 2006, 387, 467-475. [CrossRef] [PubMed]

11. Murakami, M.; Towatari, T.; Ohuchi, M.; Shiota, M.; Akao, M.; Okumura, Y.; Parry, M.A.; Kido, H. Mini-plasmin found in the epithelial cells of bronchioles triggers infection by broad-spectrum influenza A viruses and Sendai virus. Eur. J. Biochem. 2001, 268, 2847-2855. [CrossRef] [PubMed]

12. Ogasawara, T.; Gotoh, B.; Suzuki, H.; Asaka, J.; Shimokata, K.; Rott, R.; Nagai, Y. Expression of factor X and its significance for the determination of paramyxovirus tropism in the chick embryo. EMBO J. 1992, 11, 467-472. [CrossRef] [PubMed]

13. Abe, M.; Tahara, M.; Sakai, K.; Yamaguchi, H.; Kanou, K.; Shirato, K.; Kawase, M.; Noda, M.; Kimura, H.; Matsuyama, S.; et al. TMPRSS2 is an activating protease for respiratory parainfluenza viruses. J. Virol. 2013, 87, 11930-11935. [CrossRef] [PubMed]

14. Uhlen, M.; Fagerberg, L.; Hallstrom, B.M.; Lindskog, C.; Oksvold, P.; Mardinoglu, A.; Sivertsson, A.; Kampf, C.; Sjostedt, E.; Asplund, A.; et al. Proteomics. Tissue-based map of the human proteome. Science 2015, 347, 1260419. [CrossRef] [PubMed]

15. Uhlen, M.; Zhang, C.; Lee, S.; Sjostedt, E.; Fagerberg, L.; Bidkhori, G.; Benfeitas, R.; Arif, M.; Liu, Z.; Edfors, F.; et al. A pathology atlas of the human cancer transcriptome. Science 2017, 357. [CrossRef]

16. The Human Protein Atlas. Available online: https://www.proteinatlas.org/ (accessed on 20 June 2018).

17. Matveeva, O.V.; Kochneva, G.V.; Netesov, S.V.; Onikienko, S.B.; Chumakov, P.M. Mechanisms of Oncolysis by Paramyxovirus Sendai. Acta Naturae 2015, 7, 6-16. [CrossRef]

18. Matveeva, O.V.; Guo, Z.S.; Shabalina, S.A.; Chumakov, P.M. Oncolysis by paramyxoviruses: Multiple mechanisms contribute to therapeutic efficiency. Mol. Ther. Oncolytics 2015, 2, 15011. [CrossRef]

19. Matveeva, O.V.; Guo, Z.S.; Senin, V.M.; Senina, A.V.; Shabalina, S.A.; Chumakov, P.M. Oncolysis by paramyxoviruses: Preclinical and clinical studies. Mol. Ther. Oncolytics 2015, 2, 15017. [CrossRef]

20. Jiang, Y.; Qin, Y.; Chen, M. Host-Pathogen Interactions in Measles Virus Replication and Anti-Viral Immunity. Viruses 2016, 8, 308. [CrossRef]

21. Faisca, P.; Desmecht, D. Sendai virus, the mouse parainfluenza type 1: A longstanding pathogen that remains up-to-date. Res. Vet. Sci. 2007, 82, 115-125. [CrossRef]

22. Thul, P.J.; Akesson, L.; Wiking, M.; Mahdessian, D.; Geladaki, A.; Ait Blal, H.; Alm, T.; Asplund, A.; Bjork, L.; Breckels, L.M.; et al. A subcellular map of the human proteome. Science 2017, 356. [CrossRef] [PubMed]

23. International Committee on Taxonomy of Viruses. Available online: https://talk.ictvonline.org/ (accessed on 25 June 2019).

24. Griffin, D.E. Measles Virus. In Fields Virology, 6th ed.; Knipe, D.M., Howley, P.M., Eds.; Lippincott Williams \& Wilkins: Philadelphia, PA, USA, 2007; Volume 1, pp. 1042-1069.

25. Baldo, A.; Galanis, E.; Tangy, F.; Herman, P. Biosafety considerations for attenuated measles virus vectors used in virotherapy and vaccination. Hum. Vaccin. Immunother. 2016, 12, 1102-1116. [CrossRef] [PubMed]

26. Msaouel, P.; Opyrchal, M.; Domingo Musibay, E.; Galanis, E. Oncolytic measles virus strains as novel anticancer agents. Expert Opin. Biol. Ther. 2013, 6, 6. [CrossRef] [PubMed]

27. Aref, S.; Bailey, K.; Fielding, A. Measles to the Rescue: A Review of Oncolytic Measles Virus. Viruses 2016, 8, 294. [CrossRef]

28. Msaouel, P.; Opyrchal, M.; Dispenzieri, A.; Peng, K.W.; Federspiel, M.J.; Russell, S.J.; Galanis, E. Clinical Trials with Oncolytic Measles Virus: Current Status and Future Prospects. Curr. Cancer Drug Targets 2018, 18, 177-187. [CrossRef] 
29. Tatsuo, H.; Ono, N.; Tanaka, K.; Yanagi, Y. SLAM (CDw150) is a cellular receptor for measles virus. Nature 2000, 406, 893-897. [CrossRef]

30. Tatsuo, H.; Yanagi, Y. The morbillivirus receptor SLAM (CD150). Microbiol. Immunol. 2002, 46, $135-142$. [CrossRef]

31. Muhlebach, M.D.; Mateo, M.; Sinn, P.L.; Prufer, S.; Uhlig, K.M.; Leonard, V.H.; Navaratnarajah, C.K.; Frenzke, M.; Wong, X.X.; Sawatsky, B.; et al. Adherens junction protein nectin-4 is the epithelial receptor for measles virus. Nature 2011, 2, 530-533. [CrossRef]

32. Noyce, R.S.; Bondre, D.G.; Ha, M.N.; Lin, L.T.; Sisson, G.; Tsao, M.S.; Richardson, C.D. Tumor cell marker PVRL4 (nectin 4) is an epithelial cell receptor for measles virus. PLoS Pathog. 2011, 7, e1002240. [CrossRef]

33. Noyce, R.S.; Richardson, C.D. Nectin 4 is the epithelial cell receptor for measles virus. Trends Microbiol. 2012, 20, 429-439. [CrossRef]

34. Dorig, R.E.; Marcil, A.; Chopra, A.; Richardson, C.D. The human CD46 molecule is a receptor for measles virus (Edmonston strain). Cell 1993, 75, 295-305. [CrossRef]

35. Naniche, D.; Varior-Krishnan, G.; Cervoni, F.; Wild, T.F.; Rossi, B.; Rabourdin-Combe, C.; Gerlier, D. Human membrane cofactor protein (CD46) acts as a cellular receptor for measles virus. J. Virol. 1993, 67, 6025-6032. [CrossRef] [PubMed]

36. Wang, N.; Morra, M.; Wu, C.; Gullo, C.; Howie, D.; Coyle, T.; Engel, P.; Terhorst, C. CD150 is a member of a family of genes that encode glycoproteins on the surface of hematopoietic cells. Immunogenetics 2001, 53, 382-394. [CrossRef] [PubMed]

37. Sintes, J.; Romero, X.; Marin, P.; Terhorst, C.; Engel, P. Differential expression of CD150 (SLAM) family receptors by human hematopoietic stem and progenitor cells. Exp. Hematol. 2008, 36, 1199-1204. [CrossRef] [PubMed]

38. De Salort, J.; Sintes, J.; Llinas, L.; Matesanz-Isabel, J.; Engel, P. Expression of SLAM (CD150) cell-surface receptors on human B-cell subsets: From pro-B to plasma cells. Immunol. Lett. 2011, 134, 129-136. [CrossRef] [PubMed]

39. Maciejczyk, A.; Szelachowska, J.; Szynglarewicz, B.; Szulc, R.; Szulc, A.; Wysocka, T.; Jagoda, E.; Lage, H.; Surowiak, P. CD46 Expression is an unfavorable prognostic factor in breast cancer cases. Appl. Immunohistochem. Mol. Morphol. 2011, 19, 540-546. [CrossRef] [PubMed]

40. Fabre-Lafay, S.; Monville, F.; Garrido-Urbani, S.; Berruyer-Pouyet, C.; Ginestier, C.; Reymond, N.; Finetti, P.; Sauvan, R.; Adelaide, J.; Geneix, J.; et al. Nectin-4 is a new histological and serological tumor associated marker for breast cancer. BMC Cancer 2007, 7, 73. [CrossRef]

41. Athanassiadou, A.M.; Patsouris, E.; Tsipis, A.; Gonidi, M.; Athanassiadou, P. The significance of Survivin and Nectin-4 expression in the prognosis of breast carcinoma. Folia Histochemica et Cytobiologica 2011, 49, $26-33$. [CrossRef]

42. Lattanzio, R.; Ghasemi, R.; Brancati, F.; Sorda, R.L.; Tinari, N.; Perracchio, L.; Iacobelli, S.; Mottolese, M.; Natali, P.G.; Piantelli, M. Membranous Nectin-4 expression is a risk factor for distant relapse of T1-T2, N0 luminal-A early breast cancer. Oncogenesis 2014, 3, e118. [CrossRef]

43. Rajc, J.; Gugic, D.; Frohlich, I.; Marjanovic, K.; Dumencic, B. Prognostic role of Nectin-4 expression in luminal B (HER2 negative) breast cancer. Pathol. Res. Pract. 2017, 213, 1102-1108. [CrossRef]

44. Erlenhofer, C.; Duprex, W.P.; Rima, B.K.; ter Meulen, V.; Schneider-Schaulies, J. Analysis of receptor (CD46, CD150) usage by measles virus. J. Gen. Virol. 2002, 83, 1431-1436. [CrossRef] [PubMed]

45. Delpeut, S.; Sisson, G.; Black, K.M.; Richardson, C.D. Measles Virus Enters Breast and Colon Cancer Cell Lines through a PVRL4-Mediated Macropinocytosis Pathway. J. Virol. 2017, 91. [CrossRef] [PubMed]

46. Papatheodorou, I.; Fonseca, N.A.; Keays, M.; Tang, Y.A.; Barrera, E.; Bazant, W.; Burke, M.; Fullgrabe, A.; Fuentes, A.M.; George, N.; et al. Expression Atlas: Gene and protein expression across multiple studies and organisms. Nucleic Acids Res. 2018, 46, D246-D251. [CrossRef] [PubMed]

47. Allen, C.; Opyrchal, M.; Aderca, I.; Schroeder, M.A.; Sarkaria, J.N.; Domingo, E.; Federspiel, M.J.; Galanis, E. Oncolytic measles virus strains have significant antitumor activity against glioma stem cells. Gene Ther. 2012, 20, 444-449. [CrossRef]

48. Ma, J.; Sheng, Z.; Lv, Y.; Liu, W.; Yao, Q.; Pan, T.; Xu, Z.; Zhang, C.; Xu, G. Expression and clinical significance of Nectin-4 in hepatocellular carcinoma. OncoTargets Ther. 2016, 9, 183-190. [CrossRef] 
49. Takano, A.; Ishikawa, N.; Nishino, R.; Masuda, K.; Yasui, W.; Inai, K.; Nishimura, H.; Ito, H.; Nakayama, H.; Miyagi, Y.; et al. Identification of nectin-4 oncoprotein as a diagnostic and therapeutic target for lung cancer. Cancer Res. 2009, 69, 6694-6703. [CrossRef]

50. Sakuma, T.; Kodama, K.; Hara, T.; Eshita, Y.; Shibata, N.; Matsumoto, M.; Seya, T.; Mori, Y. Levels of complement regulatory molecules in lung cancer: Disappearance of the D17 epitope of CD55 in small-cell carcinoma. Jpn. J. Cancer Res. 1993, 84, 753-759. [CrossRef]

51. Gordiienko, I.M.; Shlapatska, L.M.; Kovalevska, L.M.; Sidorenko, S.P. Differential expression of CD150/SLAMF1 in normal and malignant B cells on the different stages of maturation. Exp. Oncol. 2016, 38, 101-107. [CrossRef]

52. Ong, H.T.; Timm, M.M.; Greipp, P.R.; Witzig, T.E.; Dispenzieri, A.; Russell, S.J.; Peng, K.W. Oncolytic measles virus targets high CD46 expression on multiple myeloma cells. Exp. Hematol. 2006, 34, 713-720. [CrossRef]

53. Sherbenou, D.W.; Aftab, B.T.; Su, Y.; Behrens, C.R.; Wiita, A.; Logan, A.C.; Acosta-Alvear, D.; Hann, B.C.; Walter, P.; Shuman, M.A.; et al. Antibody-drug conjugate targeting CD46 eliminates multiple myeloma cells. J. Clin. Invest. 2016, 126, 4640-4653. [CrossRef]

54. Surowiak, P.; Materna, V.; Maciejczyk, A.; Kaplenko, I.; Spaczynski, M.; Dietel, M.; Lage, H.; Zabel, M. CD46 expression is indicative of shorter revival-free survival for ovarian cancer patients. Anticancer Res. 2006, $26,4943-4948$.

55. Derycke, M.S.; Pambuccian, S.E.; Gilks, C.B.; Kalloger, S.E.; Ghidouche, A.; Lopez, M.; Bliss, R.L.; Geller, M.A.; Argenta, P.A.; Harrington, K.M.; et al. Nectin 4 overexpression in ovarian cancer tissues and serum: Potential role as a serum biomarker. Am. J. Clin. Pathol. 2010, 134, 835-845. [CrossRef]

56. Nabih, E.S.; Abdel Motaleb, F.I.; Salama, F.A. The diagnostic efficacy of nectin 4 expression in ovarian cancer patients. Biomarkers 2014, 19, 498-504. [CrossRef]

57. Nishiwada, S.; Sho, M.; Yasuda, S.; Shimada, K.; Yamato, I.; Akahori, T.; Kinoshita, S.; Nagai, M.; Konishi, N.; Nakajima, Y. Nectin-4 expression contributes to tumor proliferation, angiogenesis and patient prognosis in human pancreatic cancer. J. Exp. Clin. Cancer Res. 2015, 34, 30. [CrossRef]

58. Castro, A.G.; Hauser, T.M.; Cocks, B.G.; Abrams, J.; Zurawski, S.; Churakova, T.; Zonin, F.; Robinson, D.; Tangye, S.G.; Aversa, G.; et al. Molecular and functional characterization of mouse signaling lymphocytic activation molecule (SLAM): Differential expression and responsiveness in Th1 and Th2 cells. J. Immunol. 1999, 163, 5860-5870.

59. Vilar, M.L.; Frutuoso, M.S.; Arruda, S.M.; Lima, D.M.; Bezerra, C.S.; Pompeu, M.M. The role of the SLAM-SAP signaling pathway in the modulation of CD4+ T cell responses. Braz. J. Med. Biol. Res. 2011, 44, $276-282$. [CrossRef]

60. Quiroga, M.F.; Martinez, G.J.; Pasquinelli, V.; Costas, M.A.; Bracco, M.M.; Malbran, A.; Olivares, L.M.; Sieling, P.A.; Garcia, V.E. Activation of signaling lymphocytic activation molecule triggers a signaling cascade that enhances Th1 responses in human intracellular infection. J. Immunol. 2004, 173, 4120-4129. [CrossRef]

61. Mina, M.J.; Kula, T.; Leng, Y.; Li, M.; de Vries, R.D.; Knip, M.; Siljander, H.; Rewers, M.; Choy, D.F.; Wilson, M.S.; et al. Measles virus infection diminishes preexisting antibodies that offer protection from other pathogens. Science 2019, 366, 599-606. [CrossRef]

62. Petrova, V.N.; Sawatsky, B.; Han, A.X.; Laksono, B.M.; Walz, L.; Parker, E.; Pieper, K.; Anderson, C.A.; de Vries, R.D.; Lanzavecchia, A.; et al. Incomplete genetic reconstitution of B cell pools contributes to prolonged immunosuppression after measles. Sci. Immunol. 2019, 4. [CrossRef]

63. Sugiyama, T.; Yoneda, M.; Kuraishi, T.; Hattori, S.; Inoue, Y.; Sato, H.; Kai, C. Measles virus selectively blind to signaling lymphocyte activation molecule as a novel oncolytic virus for breast cancer treatment. Gene Ther. 2012, 21, 44. [CrossRef]

64. Awano, M.; Fujiyuki, T.; Shoji, K.; Amagai, Y.; Murakami, Y.; Furukawa, Y.; Sato, H.; Yoneda, M.; Kai, C. Measles virus selectively blind to signaling lymphocyte activity molecule has oncolytic efficacy against nectin-4-expressing pancreatic cancer cells. Cancer Sci. 2016, 107, 1647-1652. [CrossRef]

65. Fujiyuki, T.; Yoneda, M.; Amagai, Y.; Obayashi, K.; Ikeda, F.; Shoji, K.; Murakami, Y.; Sato, H.; Kai, C. A measles virus selectively blind to signaling lymphocytic activation molecule shows anti-tumor activity against lung cancer cells. Oncotarget 2015, 6, 24895-24903. [CrossRef] 
66. Leonard, V.H.; Sinn, P.L.; Hodge, G.; Miest, T.; Devaux, P.; Oezguen, N.; Braun, W.; McCray, P.B.J.; McChesney, M.B.; Cattaneo, R. Measles virus blind to its epithelial cell receptor remains virulent in rhesus monkeys but cannot cross the airway epithelium and is not shed. J. Clin. Invest. 2008, 118, 2448-2458. [CrossRef]

67. Miest, T.S.; Frenzke, M.; Cattaneo, R. Measles virus entry through the signaling lymphocyte activation molecule governs efficacy of mantle cell lymphoma radiovirotherapy. Mol. Ther. 2013, 21, 2019-2031. [CrossRef]

68. Liszewski, M.K.; Post, T.W.; Atkinson, J.P. Membrane cofactor protein (MCP or CD46): Newest member of the regulators of complement activation gene cluster. Annu. Rev. Immunol. 1991, 9, 431-455. [CrossRef]

69. Ni Choileain, S.; Astier, A.L. CD46 processing: A means of expression. Immunobiology 2012, 217, 169-175. [CrossRef]

70. Riley-Vargas, R.C.; Gill, D.B.; Kemper, C.; Liszewski, M.K.; Atkinson, J.P. CD46: Expanding beyond complement regulation. Trends Immunol. 2004, 25, 496-503. [CrossRef]

71. Buettner, R.; Huang, M.; Gritsko, T.; Karras, J.; Enkemann, S.; Mesa, T.; Nam, S.; Yu, H.; Jove, R. Activated signal transducers and activators of transcription 3 signaling induces CD46 expression and protects human cancer cells from complement-dependent cytotoxicity. Mol. Cancer Res. 2007, 5, 823-832. [CrossRef]

72. Anderson, B.D.; Nakamura, T.; Russell, S.J.; Peng, K.W. High CD46 receptor density determines preferential killing of tumor cells by oncolytic measles virus. Cancer Res. 2004, 64, 4919-4926. [CrossRef]

73. Takai, Y.; Miyoshi, J.; Ikeda, W.; Ogita, H. Nectins and nectin-like molecules: Roles in contact inhibition of cell movement and proliferation. Nat. Rev. Mol. Cell Biol. 2008, 9, 603-615. [CrossRef]

74. Samanta, D.; Almo, S.C. Nectin family of cell-adhesion molecules: Structural and molecular aspects of function and specificity. Cell. Mol. Life Sci. 2015, 72, 645-658. [CrossRef] [PubMed]

75. Delpeut, S.; Noyce, R.S.; Richardson, C.D. The tumor-associated marker, PVRL4 (nectin-4), is the epithelial receptor for morbilliviruses. Viruses 2014, 6, 2268-2286. [CrossRef] [PubMed]

76. Pavlova, N.N.; Pallasch, C.; Elia, A.E.; Braun, C.J.; Westbrook, T.F.; Hemann, M.; Elledge, S.J. A role for PVRL4-driven cell-cell interactions in tumorigenesis. Elife 2013, 2, e00358. [CrossRef]

77. Suksanpaisan, L.; Russell, S.J.; Peng, K.W. High scFv-receptor affinity does not enhance the antitumor activity of HER2-retargeted measles virus. Cancer Gene Ther. 2014, 21, 256-260. [CrossRef]

78. Hasegawa, K.; Hu, C.; Nakamura, T.; Marks, J.D.; Russell, S.J.; Peng, K.W. Affinity thresholds for membrane fusion triggering by viral glycoproteins. J. Virol. 2007, 81, 13149-13157. [CrossRef]

79. Schneider, U.; Bullough, F.; Vongpunsawad, S.; Russell, S.J.; Cattaneo, R. Recombinant measles viruses efficiently entering cells through targeted receptors. J. Virol. 2000, 74, 9928-9936. [CrossRef]

80. Hammond, A.L.; Plemper, R.K.; Zhang, J.; Schneider, U.; Russell, S.J.; Cattaneo, R. Single-chain antibody displayed on a recombinant measles virus confers entry through the tumor-associated carcinoembryonic antigen. J. Virol. 2001, 75, 2087-2096. [CrossRef]

81. Bucheit, A.D.; Kumar, S.; Grote, D.M.; Lin, Y.; von Messling, V.; Cattaneo, R.B.; Fielding, A.K. An oncolytic measles virus engineered to enter cells through the CD20 antigen. Mol. Ther. 2003, 7, 62-72. [CrossRef]

82. Peng, K.W.; Donovan, K.A.; Schneider, U.; Cattaneo, R.; Lust, J.A.; Russell, S.J. Oncolytic measles viruses displaying a single-chain antibody against CD38, a myeloma cell marker. Blood 2003, 101, 2557-2562. [CrossRef]

83. Hallak, L.K.; Merchan, J.R.; Storgard, C.M.; Loftus, J.C.; Russell, S.J. Targeted measles virus vector displaying echistatin infects endothelial cells via alpha(v)beta3 and leads to tumor regression. Cancer Res. 2005, 65, 5292-5300. [CrossRef]

84. Hammarstrom, S. The carcinoembryonic antigen (CEA) family: Structures, suggested functions and expression in normal and malignant tissues. Semin. Cancer Biol. 1999, 9, 67-81. [CrossRef] [PubMed]

85. Emerson, S.G. Ex vivo expansion of hematopoietic precursors, progenitors, and stem cells: The next generation of cellular therapeutics. Blood 1996, 87, 3082-3088. [CrossRef]

86. Sanai, N.; Alvarez-Buylla, A.; Berger, M.S. Neural stem cells and the origin of gliomas. N. Engl. J. Med. 2005, 353, 811-822. [CrossRef] [PubMed]

87. Wu, B.; Sun, C.; Feng, F.; Ge, M.; Xia, L. Do relevant markers of cancer stem cells CD133 and Nestin indicate a poor prognosis in glioma patients? A systematic review and meta-analysis. J. Exp. Clin. Cancer Res. 2015, 34, 44. [CrossRef] [PubMed] 
88. Wu, H.; Qi, X.W.; Yan, G.N.; Zhang, Q.B.; Xu, C.; Bian, X.W. Is CD133 expression a prognostic biomarker of non-small-cell lung cancer? A systematic review and meta-analysis. PLoS ONE 2014, 9, e100168. [CrossRef] [PubMed]

89. Yin, A.H.; Miraglia, S.; Zanjani, E.D.; Almeida-Porada, G.; Ogawa, M.; Leary, A.G.; Olweus, J.; Kearney, J.; Buck, D.W. AC133, a novel marker for human hematopoietic stem and progenitor cells. Blood 1997, 90, 5002-5012. [CrossRef]

90. Corbeil, D.; Roper, K.; Hellwig, A.; Tavian, M.; Miraglia, S.; Watt, S.M.; Simmons, P.J.; Peault, B.; Buck, D.W.; Huttner, W.B. The human AC133 hematopoietic stem cell antigen is also expressed in epithelial cells and targeted to plasma membrane protrusions. J. Biol. Chem. 2000, 275, 5512-5520. [CrossRef]

91. Hall, P.A.; D'Ardenne, A.J.; Richards, M.A.; Stansfeld, A.G. Lymphoplasmacytoid lymphoma: An immunohistological study. J. Pathol. 1987, 153, 213-223. [CrossRef]

92. Thomas, D.A.; O’Brien, S.; Jorgensen, J.L.; Cortes, J.; Faderl, S.; Garcia-Manero, G.; Verstovsek, S.; Koller, C.; Pierce, S.; Huh, Y.; et al. Prognostic significance of CD20 expression in adults with de novo precursor B-lineage acute lymphoblastic leukemia. Blood 2009, 113, 6330-6337. [CrossRef]

93. Fang, D.; Nguyen, T.K.; Leishear, K.; Finko, R.; Kulp, A.N.; Hotz, S.; Van Belle, P.A.; Xu, X.; Elder, D.E.; Herlyn, M. A tumorigenic subpopulation with stem cell properties in melanomas. Cancer Res. 2005, 65, 9328-9337. [CrossRef]

94. Tzankov, A.; Krugmann, J.; Fend, F.; Fischhofer, M.; Greil, R.; Dirnhofer, S. Prognostic significance of CD20 expression in classical Hodgkin lymphoma: A clinicopathological study of 119 cases. Clin. Cancer Res. 2003, 9, 1381-1386. [PubMed]

95. Li, Z.; Xu, Y.; An, G.; Wang, H.; Deng, S.; Zhao, Y.; Qiu, L. The characteristics of 62 cases of CD20-positive multiple myeloma. Zhonghua Xue Ye Xue Za Zhi 2015, 36, 44-48. [CrossRef] [PubMed]

96. Du, J.; Zhou, X.J.; Yin, H.L.; Lu, Z.F.; Zhou, H.B. Expression of CD20 in thymomas and its clinical implication. Zhonghua Bing Li Xue Za Zhi 2010, 39, 611-614. [PubMed]

97. Ibrahim, S.; Keating, M.; Do, K.A.; O’Brien, S.; Huh, Y.O.; Jilani, I.; Lerner, S.; Kantarjian, H.M.; Albitar, M. CD38 expression as an important prognostic factor in B-cell chronic lymphocytic leukemia. Blood 2001, 98, 181-186. [CrossRef] [PubMed]

98. Burgler, S. Role of CD38 Expression in Diagnosis and Pathogenesis of Chronic Lymphocytic Leukemia and Its Potential as Therapeutic Target. Crit. Rev. Immunol. 2015, 35, 417-432. [CrossRef]

99. Wang, L.; Wang, H.; Li, P.F.; Lu, Y.; Xia, Z.J.; Huang, H.Q.; Zhang, Y.J. CD38 expression predicts poor prognosis and might be a potential therapy target in extranodal NK/T cell lymphoma, nasal type. Ann. Hematol. 2015, 94, 1381-1388. [CrossRef]

100. San Miguel, J.F.; Garcia-Sanz, R.; Gonzalez, M.; Orfao, A. Immunophenotype and DNA cell content in multiple myeloma. Baillieres Clin. Haematol. 1995, 8, 735-759. [CrossRef]

101. Mitri, Z.; Constantine, T.; O'Regan, R. The HER2 Receptor in Breast Cancer: Pathophysiology, Clinical Use, and New Advances in Therapy. Chemother. Res. Pract. 2012, 2012, 743193. [CrossRef]

102. Ruschoff, J.; Hanna, W.; Bilous, M.; Hofmann, M.; Osamura, R.Y.; Penault-Llorca, F.; van de Vijver, M.; Viale, G. HER2 testing in gastric cancer: A practical approach. Mod. Pathol. 2012, 25, 637-650. [CrossRef]

103. Santin, A.D.; Bellone, S.; Roman, J.J.; McKenney, J.K.; Pecorelli, S. Trastuzumab treatment in patients with advanced or recurrent endometrial carcinoma overexpressing HER2/neu. Int. J. Gynaecol. Obstet. 2008, 102, 128-131. [CrossRef]

104. Buza, N.; Roque, D.M.; Santin, A.D. HER2/neu in Endometrial Cancer: A Promising Therapeutic Target with Diagnostic Challenges. Arch. Pathol. Lab. Med. 2014, 138, 343-350. [CrossRef]

105. Teplinsky, E.; Muggia, F. Targeting HER2 in ovarian and uterine cancers: Challenges and future directions. Gynecol. Oncol. 2014, 135, 364-370. [CrossRef] [PubMed]

106. Siena, S.; Sartore-Bianchi, A.; Marsoni, S.; Hurwitz, H.I.; McCall, S.J.; Penault-Llorca, F.; Srock, S.; Bardelli, A.; Trusolino, L. Targeting the human epidermal growth factor receptor 2 (HER2) oncogene in colorectal cancer. Ann. Oncol. 2018, 29, 1108-1119. [CrossRef]

107. Tang, T.; Zhang, D.L. Study on extracellular matrix metalloproteinase inducer and human epidermal growth factor receptor-2 protein expression in papillary thyroid carcinoma using a quantum dot-based immunofluorescence technique. Exp. Ther. Med. 2015, 9, 1331-1335. [CrossRef] 
108. Kumar, S.; Prajapati, O.; Vaiphei, K.; Parmar, K.M.; Sriharsha, A.S.; Singh, S.K. Human epidermal growth factor receptor $2 /$ neu overexpression in urothelial carcinoma of the bladder and its prognostic significance: Is it worth hype? South Asian J. Cancer 2015, 4, 115-117. [CrossRef]

109. Hasegawa, K.; Nakamura, T.; Harvey, M.; Ikeda, Y.; Oberg, A.; Figini, M.; Canevari, S.; Hartmann, L.C.; Peng, K.W. The use of a tropism-modified measles virus in folate receptor-targeted virotherapy of ovarian cancer. Clin. Cancer Res. 2006, 12, 6170-6178. [CrossRef]

110. Chang, S.S. Overview of prostate-specific membrane antigen. Rev. Urol. 2004, 6, S13-S18.

111. Lal, S.; Raffel, C. Using Cystine Knot Proteins as a Novel Approach to Retarget Oncolytic Measles Virus. Mol. Ther. Oncolytics 2017, 7, 57-66. [CrossRef]

112. Vongpunsawad, S.; Oezgun, N.; Braun, W.; Cattaneo, R. Selectively receptor-blind measles viruses: Identification of residues necessary for SLAM- or CD46-induced fusion and their localization on a new hemagglutinin structural model. J. Virol. 2004, 78, 302-313. [CrossRef]

113. Hadac, E.M.; Peng, K.W.; Nakamura, T.; Russell, S.J. Reengineering paramyxovirus tropism. Virology 2004, 329, 217-225. [CrossRef]

114. Nakamura, T.; Peng, K.W.; Harvey, M.; Greiner, S.; Lorimer, I.A.; James, C.D.; Russell, S.J. Rescue and propagation of fully retargeted oncolytic measles viruses. Nat. Biotechnol. 2005, 23, 209-214. [CrossRef]

115. Bach, P.; Abel, T.; Hoffmann, C.; Gal, Z.; Braun, G.; Voelker, I.; Ball, C.R.; Johnston, I.C.; Lauer, U.M.; Herold-Mende, C.; et al. Specific Elimination of CD133+ Tumor Cells with Targeted Oncolytic Measles Virus. Cancer Res. 2013, 4, 4. [CrossRef]

116. Kleinlutzum, D.; Hanauer, J.D.S.; Muik, A.; Hanschmann, K.M.; Kays, S.K.; Ayala-Breton, C.; Peng, K.W.; Muhlebach, M.D.; Abel, T.; Buchholz, C.J. Enhancing the Oncolytic Activity of CD133-Targeted Measles Virus: Receptor Extension or Chimerism with Vesicular Stomatitis Virus Are Most Effective. Front. Oncol. 2017, 7, 127. [CrossRef]

117. Jing, Y.; Bejarano, M.T.; Zaias, J.; Merchan, J.R. In vivo anti-metastatic effects of uPAR retargeted measles virus in syngeneic and xenograft models of mammary cancer. Breast Cancer Res. Treat. 2015, 149, 99-108. [CrossRef]

118. Jing, Y.; Chavez, V.; Ban, Y.; Acquavella, N.; El-Ashry, D.; Pronin, A.; Chen, X.; Merchan, J.R. Molecular Effects of Stromal-Selective Targeting by uPAR-Retargeted Oncolytic Virus in Breast Cancer. Mol. Cancer Res. 2017, 15, 1410-1420. [CrossRef]

119. Friedrich, K.; Hanauer, J.R.; Prufer, S.; Munch, R.C.; Volker, I.; Filippis, C.; Jost, C.; Hanschmann, K.M.; Cattaneo, R.; Peng, K.W.; et al. DARPin-targeting of measles virus: Unique bispecificity, effective oncolysis, and enhanced safety. Mol. Ther. 2013, 21, 849-859. [CrossRef]

120. Hanauer, J.R.; Gottschlich, L.; Riehl, D.; Rusch, T.; Koch, V.; Friedrich, K.; Hutzler, S.; Prufer, S.; Friedel, T.; Hanschmann, K.M.; et al. Enhanced lysis by bispecific oncolytic measles viruses simultaneously using HER2/neu or EpCAM as target receptors. Mol. Ther. Oncolytics 2016, 3, 16003. [CrossRef]

121. Hanauer, J.R.H.; Koch, V.; Lauer, U.M.; Muhlebach, M.D. High-Affinity DARPin Allows Targeting of $\mathrm{MeV}$ to Glioblastoma Multiforme in Combination with Protease Targeting without Loss of Potency. Mol. Ther. Oncolytics 2019, 15, 186-200. [CrossRef]

122. Liu, C.; Hasegawa, K.; Russell, S.J.; Sadelain, M.; Peng, K.W. Prostate-specific membrane antigen retargeted measles virotherapy for the treatment of prostate cancer. Prostate 2009, 69, 1128-1141. [CrossRef]

123. Slobod, K.S.; Shenep, J.L.; Lujan-Zilbermann, J.; Allison, K.; Brown, B.; Scroggs, R.A.; Portner, A.; Coleclough, C.; Hurwitz, J.L. Safety and immunogenicity of intranasal murine parainfluenza virus type 1 (Sendai virus) in healthy human adults. Vaccine 2004, 22, 3182-3186. [CrossRef]

124. Adderson, E.; Branum, K.; Sealy, R.E.; Jones, B.G.; Surman, S.L.; Penkert, R.; Freiden, P.; Slobod, K.S.; Gaur, A.H.; Hayden, R.T.; et al. Safety and immunogenicity of an intranasal Sendai virus-based human parainfluenza virus type 1 vaccine in 3- to 6-year-old children. Clin. Vaccine Immunol. 2015, 22, 298-303. [CrossRef]

125. Nyombayire, J.; Anzala, O.; Gazzard, B.; Karita, E.; Bergin, P.; Hayes, P.; Kopycinski, J.; Omosa-Manyonyi, G.; Jackson, A.; Bizimana, J.; et al. First-in-Human Evaluation of the Safety and Immunogenicity of an Intranasally Administered Replication-Competent Sendai Virus-Vectored HIV Type 1 Gag Vaccine: Induction of Potent T-Cell or Antibody Responses in Prime-Boost Regimens. J. Infect. Dis. 2017, 215, 95-104. [CrossRef]

126. Ishii, H.; Matano, T. Development of an AIDS vaccine using Sendai virus vectors. Vaccine 2015, 33, 6061-6065. [CrossRef] 
127. Moriya, C.; Horiba, S.; Kurihara, K.; Kamada, T.; Takahara, Y.; Inoue, M.; Iida, A.; Hara, H.; Shu, T.; Hasegawa, M.; et al. Intranasal Sendai viral vector vaccination is more immunogenic than intramuscular under pre-existing anti-vector antibodies. Vaccine 2011, 29, 8557-8563. [CrossRef]

128. Institute of Laboratory Animal Resources Committee on Infectious Diseases of Mice and Rats. Infectious Diseases of Mice and Rats; National Academy Press: Washington, WA, USA, 1991; p. xi. 397p.

129. Nagai, Y.; Takakura, A.; Irie, T.; Yonemitsu, Y.; Gotoh, B. Evolution of Sendai Virus: The Journey from Mouse Pathogen to a State-of-the-Art Tool in Virus Research and Biotechnology. In The Biology of Paramyxoviruses; Caister Academic Press: Maryland, MD, USA, 2011.

130. Ilyinskaya, G.V.; Mukhina, E.V.; Soboleva, A.V.; Matveeva, O.V.; Chumakov, P.M. Oncolytic Sendai Virus Therapy of Canine Mast Cell Tumors (A Pilot Study). Front. Vet. Sci. 2018, 5, 116. [CrossRef]

131. Kinoh, H.; Inoue, M.; Washizawa, K.; Yamamoto, T.; Fujikawa, S.; Tokusumi, Y.; Iida, A.; Nagai, Y.; Hasegawa, M. Generation of a recombinant Sendai virus that is selectively activated and lyses human tumor cells expressing matrix metalloproteinases. Gene Ther. 2004, 11, 1137-1145. [CrossRef]

132. Yonemitsu, Y.; Ueda, Y.; Kinoh, H.; Hasegawa, M. Immunostimulatory virotherapy using recombinant Sendai virus as a new cancer therapeutic regimen. Front. Biosci. 2008, 13, 1892-1898. [CrossRef]

133. Kinoh, H.; Inoue, M. New cancer therapy using genetically-engineered oncolytic Sendai virus vector. Front. Biosci. 2008, 13, 2327-2334. [CrossRef]

134. Tatsuta, K.; Tanaka, S.; Tajiri, T.; Shibata, S.; Komaru, A.; Ueda, Y.; Inoue, M.; Hasegawa, M.; Suita, S.; Sueishi, K.; et al. Complete elimination of established neuroblastoma by synergistic action of gamma-irradiation and DCs treated with rSeV expressing interferon-beta gene. Gene Ther. 2009, 16, 240-251. [CrossRef]

135. Iwadate, Y.; Inoue, M.; Saegusa, T.; Tokusumi, Y.; Kinoh, H.; Hasegawa, M.; Tagawa, M.; Yamaura, A.; Shimada, H. Recombinant Sendai virus vector induces complete remission of established brain tumors through efficient interleukin-2 gene transfer in vaccinated rats. Clin. Cancer Res. 2005, 11, 3821-3827. [CrossRef]

136. Kurooka, M.; Kaneda, Y. Inactivated Sendai virus particles eradicate tumors by inducing immune responses through blocking regulatory T cells. Cancer Res. 2007, 67, 227-236. [CrossRef]

137. Kawano, H.; Komaba, S.; Kanamori, T.; Kaneda, Y. A new therapy for highly effective tumor eradication using HVJ-E combined with chemotherapy. BMC Med. 2007, 5, 28. [CrossRef]

138. Kawano, H.; Komaba, S.; Yamasaki, T.; Maeda, M.; Kimura, Y.; Maeda, A.; Kaneda, Y. New potential therapy for orthotopic bladder carcinoma by combining HVJ envelope with doxorubicin. Cancer Chemother. Pharmacol. 2008, 61, 973-978. [CrossRef]

139. Fujihara, A.; Kurooka, M.; Miki, T.; Kaneda, Y. Intratumoral injection of inactivated Sendai virus particles elicits strong antitumor activity by enhancing local CXCL10 expression and systemic NK cell activation. Cancer Immunol. Immunother. 2008, 57, 73-84. [CrossRef]

140. Kawaguchi, Y.; Miyamoto, Y.; Inoue, T.; Kaneda, Y. Efficient eradication of hormone-resistant human prostate cancers by inactivated Sendai virus particle. Int. J. Cancer 2009, 124, 2478-2487. [CrossRef]

141. Lallemand, C.; Blanchard, B.; Palmieri, M.; Lebon, P.; May, E.; Tovey, M.G. Single-stranded RNA viruses inactivate the transcriptional activity of p53 but induce NOXA-dependent apoptosis via post-translational modifications of IRF-1, IRF-3 and CREB. Oncogene 2007, 26, 328-338. [CrossRef]

142. Shah, N.R.; Sunderland, A.; Grdzelishvili, V.Z. Cell type mediated resistance of vesicular stomatitis virus and Sendai virus to ribavirin. PLoS ONE 2010, 5, e11265. [CrossRef]

143. Takeuchi, K.; Komatsu, T.; Kitagawa, Y.; Sada, K.; Gotoh, B. Sendai virus C protein plays a role in restricting PKR activation by limiting the generation of intracellular double-stranded RNA. J. Virol. 2008, 82, 10102-10110. [CrossRef]

144. Zainutdinov, S.S.; Grazhdantseva, A.A.; Kochetkov, D.V.; Chumakov, P.M.; Netesov, S.V.; Matveeva, O.V.; Kochneva, G.V. Change in Oncolytic Activity of Sendai Virus during Adaptation to Cell Cultures. Mol. Gen. Microbiol. Virol. 2017, 32, 212-217. [CrossRef]

145. Bitzer, M.; Lauer, U.; Baumann, C.; Spiegel, M.; Gregor, M.; Neubert, W.J. Sendai virus efficiently infects cells via the asialoglycoprotein receptor and requires the presence of cleaved F0 precursor proteins for this alternative route of cell entry. J. Virol. 1997, 71, 5481-5486. [CrossRef]

146. Keskinen, P.; Nyqvist, M.; Sareneva, T.; Pirhonen, J.; Melen, K.; Julkunen, I. Impaired antiviral response in human hepatoma cells. Virology 1999, 263, 364-375. [CrossRef] 
147. Sumpter, R.J.; Loo, Y.M.; Foy, E.; Li, K.; Yoneyama, M.; Fujita, T.; Lemon, S.M.; Gale, M.J. Regulating intracellular antiviral defense and permissiveness to hepatitis $C$ virus RNA replication through a cellular RNA helicase, RIG-I. J. Virol. 2005, 79, 2689-2699. [CrossRef]

148. Buggele, W.A.; Horvath, C.M. MicroRNA profiling of Sendai virus-infected A549 cells identifies miR-203 as an interferon-inducible regulator of IFIT1/ISG56. J. Virol. 2013, 87, 9260-9270. [CrossRef]

149. Bedsaul, J.R.; Zaritsky, L.A.; Zoon, K.C. Type I Interferon-Mediated Induction of Antiviral Genes and Proteins Fails to Protect Cells from the Cytopathic Effects of Sendai Virus Infection. J. Interferon Cytokine Res. 2016, 36, 652-665. [CrossRef]

150. Genoyer, E.; Kulej, K.; Hung, C.T.; Thibault, P.A.; Azarm, K.; Takimoto, T.; Garcia, B.A.; Lee, B.; Lakdawala, S.; Weitzman, M.D.; et al. The Viral Polymerase Complex Mediates the Interaction of Viral Ribonucleoprotein Complexes with Recycling Endosomes during Sendai Virus Assembly. mBio 2020, 11. [CrossRef]

151. Mandhana, R.; Horvath, C.M. Sendai Virus Infection Induces Expression of Novel RNAs in Human Cells. Sci. Rep. 2018, 8, 16815. [CrossRef]

152. Belova, A.A.; Sosnovtseva, A.O.; Lipatova, A.V.; Njushko, K.M.; Volchenko, N.N.; Belyakov, M.M.; Sudalenko, O.V.; Krasheninnikov, A.A.; Shegai, P.V.; Sadritdinova, A.F.; et al. Biomarkers of prostate cancer sensitivity to the Sendai virus. Mol. Biol. 2017, 51, 94-103. [CrossRef]

153. Wheelock, E.F.; Dingle, J.H. Observations on the Repeated Administration of Viruses to a Patient with Acute Leukemia. A Preliminary Report. N. Engl. J. Med. 1964, 271, 645-651. [CrossRef]

154. Senina, A.; Matveeva, O.; Senin, V. Method for Cancer Immunotherapy and Pharmaceutical Compositions Based on Oncolytic Non-Pathogenic Sendai Virus. US Patent 9526779, 27 December 2016.

155. Suzuki, Y.; Suzuki, T.; Matsumoto, M. Isolation and characterization of receptor sialoglycoprotein for hemagglutinating virus of Japan (Sendai virus) from bovine erythrocyte membrane. J. Biochem. 1983, 93, 1621-1633. [CrossRef]

156. Markwell, M.A.; Portner, A.; Schwartz, A.L. An alternative route of infection for viruses: Entry by means of the asialoglycoprotein receptor of a Sendai virus mutant lacking its attachment protein. Proc. Natl. Acad. Sci. USA 1985, 82, 978-982. [CrossRef]

157. Wybenga, L.E.; Epand, R.F.; Nir, S.; Chu, J.W.; Sharom, F.J.; Flanagan, T.D.; Epand, R.M. Glycophorin as a receptor for Sendai virus. Biochemistry 1996, 35, 9513-9518. [CrossRef]

158. Muthing, J. Influenza A and Sendai viruses preferentially bind to fucosylated gangliosides with linear poly-N-acetyllactosaminyl chains from human granulocytes. Carbohydr. Res. 1996, 290, 217-224. [CrossRef]

159. Villar, E.; Barroso, I.M. Role of sialic acid-containing molecules in paramyxovirus entry into the host cell: A minireview. Glycoconj. J. 2006, 23, 5-17. [CrossRef]

160. Macher, B.A.; Beckstead, J.H. Distribution of VIM-2 and SSEA-1 glycoconjugate epitopes among human leukocytes and leukemia cells. Leuk. Res. 1990, 14, 119-130. [CrossRef]

161. Holmgren, J.; Svennerholm, L.; Elwing, H.; Fredman, P.; Strannegard, O. Sendai virus receptor: Proposed recognition structure based on binding to plastic-adsorbed gangliosides. Proc. Natl. Acad. Sci. USA 1980, 77, 1947-1950. [CrossRef]

162. Markwell, M.A.; Svennerholm, L.; Paulson, J.C. Specific gangliosides function as host cell receptors for Sendai virus. Proc. Natl. Acad. Sci. USA 1981, 78, 5406-5410. [CrossRef]

163. Suzuki, Y.; Suzuki, T.; Matsunaga, M.; Matsumoto, M. Gangliosides as paramyxovirus receptor. Structural requirement of sialo-oligosaccharides in receptors for hemagglutinating virus of Japan (Sendai virus) and Newcastle disease virus. J. Biochem. 1985, 97, 1189-1199. [CrossRef]

164. Yu, R.K.; Tsai, Y.T.; Ariga, T.; Yanagisawa, M. Structures, biosynthesis, and functions of gangliosides-An overview. J. Oleo Sci. 2011, 60, 537-544. [CrossRef]

165. Suzuki, T.; Portner, A.; Scroggs, R.A.; Uchikawa, M.; Koyama, N.; Matsuo, K.; Suzuki, Y.; Takimoto, T. Receptor specificities of human respiroviruses. J. Virol. 2001, 75, 4604-4613. [CrossRef]

166. Umeda, M.; Nojima, S.; Inoue, K. Activity of human erythrocyte gangliosides as a receptor to HVJ. Virology 1984, 133, 172-182. [CrossRef]

167. Liang, J.X.; Liang, Y.; Gao, W. Clinicopathological and prognostic significance of sialyl Lewis X overexpression in patients with cancer: A meta-analysis. OncoTargets Ther. 2016, 9, 3113-3125. [CrossRef]

168. Ogawa, J.; Sano, A.; Inoue, H.; Koide, S. Expression of Lewis-related antigen and prognosis in stage I non-small cell lung cancer. Ann. Thorac. Surg. 1995, 59, 412-415. [CrossRef] 
169. Yu, C.J.; Shih, J.Y.; Lee, Y.C.; Shun, C.T.; Yuan, A.; Yang, P.C. Sialyl Lewis antigens: Association with MUC5AC protein and correlation with post-operative recurrence of non-small cell lung cancer. Lung Cancer 2005, 47, 59-67. [CrossRef]

170. Sterner, E.; Flanagan, N.; Gildersleeve, J.C. Perspectives on Anti-Glycan Antibodies Gleaned from Development of a Community Resource Database. ACS Chem. Biol. 2016, 11, 1773-1783. [CrossRef]

171. Fukuoka, K.; Narita, N.; Saijo, N. Increased expression of sialyl Lewis(x) antigen is associated with distant metastasis in lung cancer patients: Immunohistochemical study on bronchofiberscopic biopsy specimens. Lung Cancer 1998, 20, 109-116. [CrossRef]

172. Nakamori, S.; Kameyama, M.; Imaoka, S.; Furukawa, H.; Ishikawa, O.; Sasaki, Y.; Izumi, Y.; Irimura, T. Involvement of carbohydrate antigen sialyl Lewis(x) in colorectal cancer metastasis. Dis. Colon Rectum 1997, 40, 420-431. [CrossRef]

173. Nakagoe, T.; Fukushima, K.; Tanaka, K.; Sawai, T.; Tsuji, T.; Jibiki, M.; Nanashima, A.; Yamaguchi, H.; Yasutake, T.; Ayabe, H.; et al. Evaluation of sialyl Lewis(a), sialyl Lewis(x), and sialyl Tn antigens expression levels as predictors of recurrence after curative surgery in node-negative colorectal cancer patients. J. Exp. Clin. Cancer Res. 2002, 21, 107-113.

174. Yamadera, M.; Shinto, E.; Tsuda, H.; Kajiwara, Y.; Naito, Y.; Hase, K.; Yamamoto, J.; Ueno, H. Sialyl Lewis(x) expression at the invasive front as a predictive marker of liver recurrence in stage II colorectal cancer. Oncol. Lett. 2018, 15, 221-228. [CrossRef]

175. Nakagoe, T.; Fukushima, K.; Sawai, T.; Tsuji, T.; Jibiki, M.; Nanashima, A.; Tanaka, K.; Yamaguchi, H.; Yasutake, T.; Ayabe, H.; et al. Increased expression of sialyl Lewis(x) antigen as a prognostic factor in patients with stage 0, I, and II gastric cancer. Cancer Lett. 2002, 175, 213-221. [CrossRef]

176. Trinchera, M.; Aronica, A.; Dall'Olio, F. Selectin Ligands Sialyl-Lewis a and Sialyl-Lewis x in Gastrointestinal Cancers. Biology 2017, 6, 16. [CrossRef]

177. Nakagoe, T.; Fukushima, K.; Itoyanagi, N.; Ikuta, Y.; Oka, T.; Nagayasu, T.; Ayabe, H.; Hara, S.; Ishikawa, H.; Minami, H. Expression of ABH/Lewis-related antigens as prognostic factors in patients with breast cancer. J. Cancer Res. Clin. Oncol. 2002, 128, 257-264. [CrossRef] [PubMed]

178. Jeschke, U.; Mylonas, I.; Shabani, N.; Kunert-Keil, C.; Schindlbeck, C.; Gerber, B.; Friese, K. Expression of sialyl Lewis X, Sialyl Lewis A, E-cadherin and cathepsin-D in human breast cancer: Immunohistochemical analysis in mammary carcinoma in situ, invasive carcinomas and their lymph node metastasis. Anticancer Res. 2005, 25, 1615-1622.

179. Carrascal, M.A.; Silva, M.; Ferreira, J.A.; Azevedo, R.; Ferreira, D.; Silva, A.M.N.; Ligeiro, D.; Santos, L.L.; Sackstein, R.; Videira, P.A. A functional glycoproteomics approach identifies CD13 as a novel E-selectin ligand in breast cancer. Biochimica et Biophysica Acta 2018. [CrossRef] [PubMed]

180. Dimitroff, C.J.; Lechpammer, M.; Long-Woodward, D.; Kutok, J.L. Rolling of human bone-metastatic prostate tumor cells on human bone marrow endothelium under shear flow is mediated by E-selectin. Cancer Res. 2004, 64, 5261-5269. [CrossRef]

181. Munkley, J. Glycosylation is a global target for androgen control in prostate cancer cells. Endocr. Relat. Cancer 2017, 24, R49-R64. [CrossRef]

182. Idikio, H.A. Sialyl-Lewis-X, Gleason grade and stage in non-metastatic human prostate cancer. Glycoconj. J. 1997, 14, 875-877. [CrossRef] [PubMed]

183. Takada, A.; Ohmori, K.; Yoneda, T.; Tsuyuoka, K.; Hasegawa, A.; Kiso, M.; Kannagi, R. Contribution of carbohydrate antigens sialyl Lewis A and Sialyl Lewis $\mathrm{X}$ to adhesion of human cancer cells to vascular endothelium. Cancer Res. 1993, 53, 354-361. [PubMed]

184. Majdic, O.; Bettelheim, P.; Stockinger, H.; Aberer, W.; Liszka, K.; Lutz, D.; Knapp, W. M2, a novel myelomonocytic cell surface antigen and its distribution on leukemic cells. Int. J. Cancer 1984, 33, 617-623. [CrossRef]

185. Noguchi, M.; Sato, N.; Sugimori, H.; Mori, K.; Oshimi, K. A minor E-selectin ligand, CD65, is critical for extravascular infiltration of acute myeloid leukemia cells. Leuk. Res. 2001, 25, 847-853. [CrossRef]

186. Liang, Y.J.; Ding, Y.; Levery, S.B.; Lobaton, M.; Handa, K.; Hakomori, S.I. Differential expression profiles of glycosphingolipids in human breast cancer stem cells vs. cancer non-stem cells. Proc. Natl. Acad. Sci. USA 2013, 110, 4968-4973. [CrossRef] 
187. Hatano, K.; Miyamoto, Y.; Nonomura, N.; Kaneda, Y. Expression of gangliosides, GD1a, and sialyl paragloboside is regulated by NF-kB-dependent transcriptional control of $\alpha 2,3$-sialyltransferase I, II, and VI in human castration-resistant prostate cancer cells. Int. J. Cancer 2011, 129, 1838-1847. [CrossRef] [PubMed]

188. Hamasaki, H.; Aoyagi, M.; Kasama, T.; Handa, S.; Hirakawa, K.; Taki, T. GT1b in human metastatic brain tumors: GT1b as a brain metastasis-associated ganglioside. Biochimica et Biophysica Acta 1999, 1437, 93-99. [CrossRef]

189. Merritt, W.D.; Sztein, M.B.; Taylor, B.; Reaman, G.H. Immunoreactivity of leukemic lymphoblasts of T-cell and B-cell precursor origin with monoclonal anti-GD3 and anti-GM3 antibodies. Leukemia 1991, 5, 1087-1091. [PubMed]

190. Westrick, M.A.; Lee, W.M.; Macher, B.A. Isolation and characterization of gangliosides from chronic myelogenous leukemia cells. Cancer Res. 1983, 43, 5890-5894.

191. Hara, H.; Hara, H.; Hironaka, T.; Inoue, M.; Iida, A.; Shu, T.; Hasegawa, M.; Nagai, Y.; Falsey, A.R.; Kamali, A.; et al. Prevalence of specific neutralizing antibodies against Sendai virus in populations from different geographic areas: Implications for AIDS vaccine development using Sendai virus vectors. Hum. Vaccin. 2011, 7, 639-645. [CrossRef]

192. Makela, M.J.; Marusyk, R.G.; Norrby, E.; Tyrrell, D.L.; Salmi, A.A. Antibodies to measles virus surface polypeptides in an immunized student population before and after booster vaccination. Vaccine 1989, 7,541-545. [CrossRef]

193. Roy, D.G.; Bell, J.C. Cell carriers for oncolytic viruses: Current challenges and future directions. Oncolytic Virother. 2013, 2, 47-56. [CrossRef]

194. Ong, H.T.; Federspiel, M.J.; Guo, C.M.; Ooi, L.L.; Russell, S.J.; Peng, K.W.; Hui, K.M. Systemically delivered measles virus-infected mesenchymal stem cells can evade host immunity to inhibit liver cancer growth. J. Hepatol. 2013, 16, 00451-00457. [CrossRef]

195. Grosjean, I.; Caux, C.; Bella, C.; Berger, I.; Wild, F.; Banchereau, J.; Kaiserlian, D. Measles virus infects human dendritic cells and blocks their allostimulatory properties for CD4+ T cells. J. Exp. Med. 1997, 186, 801-812. [CrossRef]

196. de Swart, R.L.; Ludlow, M.; de Witte, L.; Yanagi, Y.; van Amerongen, G.; McQuaid, S.; Yuksel, S.; Geijtenbeek, T.B.; Duprex, W.P.; Osterhaus, A.D. Predominant infection of CD150+ lymphocytes and dendritic cells during measles virus infection of macaques. PLoS Pathog. 2007, 3, e178. [CrossRef]

197. Derakhshani, S.; Kurz, A.; Japtok, L.; Schumacher, F.; Pilgram, L.; Steinke, M.; Kleuser, B.; Sauer, M.; Schneider-Schaulies, S.; Avota, E. Measles Virus Infection Fosters Dendritic Cell Motility in a 3D Environment to Enhance Transmission to Target Cells in the Respiratory Epithelium. Front. Immunol. 2019, 10, 1294. [CrossRef] [PubMed]

198. Kiener, R.; Fleischmann, M.; Wiegand, M.A.; Lemmermann, N.A.W.; Schwegler, C.; Kaufmann, C.; Renzaho, A.; Thomas, S.; Felder, E.; Niller, H.H.; et al. Efficient Delivery of Human Cytomegalovirus T Cell Antigens by Attenuated Sendai Virus Vectors. J. Virol. 2018, 92. [CrossRef] [PubMed]

199. Shibata, S.; Okano, S.; Yonemitsu, Y.; Onimaru, M.; Sata, S.; Nagata-Takeshita, H.; Inoue, M.; Zhu, T.; Hasegawa, M.; Moroi, Y.; et al. Induction of efficient antitumor immunity using dendritic cells activated by recombinant Sendai virus and its modulation by exogenous IFN- $\beta$ gene. J. Immunol. 2006, 177, 3564-3576. [CrossRef] [PubMed]

200. Ilett, E.J.; Prestwich, R.J.; Kottke, T.; Errington, F.; Thompson, J.M.; Harrington, K.J.; Pandha, H.S.; Coffey, M.; Selby, P.J.; Vile, R.G.; et al. Dendritic cells and T cells deliver oncolytic reovirus for tumour killing despite pre-existing anti-viral immunity. Gene Ther. 2009, 16, 689-699. [CrossRef] [PubMed]

201. Ilett, E.J.; Barcena, M.; Errington-Mais, F.; Griffin, S.; Harrington, K.J.; Pandha, H.S.; Coffey, M.; Selby, P.J.; Limpens, R.W.; Mommaas, M.; et al. Internalization of oncolytic reovirus by human dendritic cell carriers protects the virus from neutralization. Clin. Cancer Res. 2011, 17, 2767-2776. [CrossRef] [PubMed]

202. Aref, S.; Castleton, A.Z.; Bailey, K.; Burt, R.; Dey, A.; Leongamornlert, D.; Mitchell, R.J.; Okasha, D.; Fielding, A.K. Type 1 Interferon Responses Underlie Tumor-Selective Replication of Oncolytic Measles Virus. Mol. Ther. 2020, 28, 1043-1055. [CrossRef] [PubMed] 
203. Allagui, F.; Achard, C.; Panterne, C.; Combredet, C.; Labarriere, N.; Dreno, B.; Elgaaied, A.B.; Pouliquen, D.; Tangy, F.; Fonteneau, J.F.; et al. Modulation of the Type I Interferon Response Defines the Sensitivity of Human Melanoma Cells to Oncolytic Measles Virus. Curr. Gene Ther. 2017, 16, 419-428. [CrossRef]

204. Tanabe, L.M.; List, K. The role of type II transmembrane serine protease-mediated signaling in cancer. FEBS J. 2017, 284, 1421-1436. [CrossRef]

Publisher's Note: MDPI stays neutral with regard to jurisdictional claims in published maps and institutional affiliations.

(C) 2020 by the authors. Licensee MDPI, Basel, Switzerland. This article is an open access article distributed under the terms and conditions of the Creative Commons Attribution (CC BY) license (http://creativecommons.org/licenses/by/4.0/). 